\title{
RESPOSTAS FISIOLÓGICAS, BIOQUIMICA E PRODUTIVAS DO CAPIM-MOMBAÇA A DOSES DE NITROGÊNIO
}

\section{CIRLENE APARECIDA MANARIN}

Engenheira Agrônoma

Orientador: Prof. Dr. FRANCISCO ANTONIO MONTEIRO

Dissertação apresentada à Escola Superior de Agricultura "Luiz de Queiroz", da Universidade de São Paulo, para a obtenção do título de Mestre em Agronomia, Área de Concentração: Solos e Nutrição de Plantas

PIRACICABA

Estado de São Paulo - Brasil

Outubro-2000 
Dados Internacionais de Catalogação na Publicação (CIP) DIVISÃo DE BIBLIOTECA E DOCUMENTAÇÃO - Campus "Luiz de Queiroz"/USP

Manarin, Cirtene Aparecida

Respostas fisiológicas, bioquímica e produtivas do capim-mombaça a doses de nitrogênio / Cirlene Aparecida Manarin. - - Piracicaba, 2000.

59 p. : il.

Dissertação (mestrado) - - Escola Superior de Agricultura Luiz de Queiroz, 2000.

Bibliografia.

1. Capim mombaça 2. Clorofila 3. Dosagem 4. Nitrogênio 5. Perfilhação 6.

Produtividade 7. Redutase do nitrato 8 . Suprimento I. Título

CDD 633.2

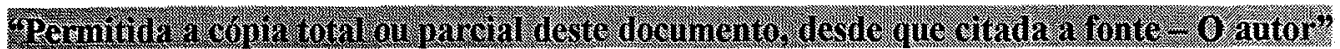


Aos meus pais Orlando Manarin

e Clarisse Bernardi Manarin (in memorian)

\section{DEDICO}

Aos meus irmãos Sueli, Sidinei, Sandra e Simeire, e em especial ao Cláudio, hoje meu marido 


\section{AGRADECIMENTOS}

Ao Prof. Dr. Francisco Antonio Monteiro, pela orientação, apoio e amizade.

Ao Prof. Dr. Quirino Augusto de Camargo Carmello pela amizade e sugestões.

Ao Prof. Dr. Antônio Roque Dechen pela convivência e aprendizagem.

Ao Prof. Dr. Godofredo Cesar Vitti pela orientação na graduação, sugestões e amizade.

A todos os professores do Curso de Solos e Nutrição de Plantas, pela dedicação e conhecimentos transmitidos.

Ao Prof. Dr. Ricardo Ferraz de Oliveira pela colaboração e pela amizade.

Aos funcionários Sueli M. A. C. Bovi, Nivanda M. de Moura, Lúcia H. S. P. Forti, Edinéia C. S. Mondoni, Mirtes V. Sesso, Nancy Campos Amaral pela valiosa contribuição na realização do trabalho e pela amizade.

Aos estagiários de Nutrição Mineral de Plantas, em especial ao Pelerson Furlan Schiavuzzo e ao José Lavres Júnior pela ajuda, dedicação e amizade.

Aos companheiros de curso e amigos, com um carinho especial por Gláucia Regina Anti, Walcylene L. M. Pereira e Waldssimiller Teixeira de Mattos pela amizade, incentivo e ajuda.

A minha irmã Simeire Aparecida Manarin pela imensa contribuição para a realização deste trabalho.

Ao meu marido Cláudio Leitão Ronsini por toda paciência, amor e incentivo nestes anos todos.

Ao CNPq e a FAPESP pelos apoios financeiro e institucional prestado para a realização deste trabalho. 
ÍNDICE

Pág.

RESUMO

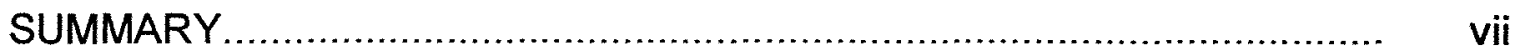

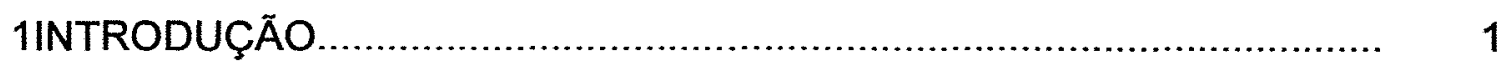

2 REVISÄO DE LITERATURA ........................................................... 3

2.1 Panicum maximum Jacq. cultivar Mombaça......................................... 3

2.2 Nitrogênio e produção de matéria seca da forrageira......................... 5

2.3 Perfilhamento .......................................................................... 8

2.4 Área foliar do capim-Mombaça......................................................... 10

2.5 Atividade da redutase do nitrato................................................... 11

2.6 Estimativa do teor de clorofila através do valor SPAD....................... 12

2.7 Amostragem de tecido vegetal e nível crítico....................................... 14

3 MATERIAL E MÉTODOS................................................................ 16

3.1 Localização, época e gramínea....................................................... 16

3.2 Doses de nutrientes, soluções nutritivas e delineamento experimental 16

3.3 Instalação e condução do experimento............................................ 17

3.4 Coleta do material vegetal ............................................................. 18

3.5 Avaliações no material vegetal........................................................ 19

3.5.1 Produção de matéria seca e perfilhos.............................................. 19

3.5.2 Atividade da redutase do nitrato.................................................. 19

3.5.3 Estimativa do teor de clorofila através do valor SPAD ...................... 20

3.5.4 Composição mineral do tecido vegetal............................................ 21

3.6 Análises estatísticas....................................................................... 21

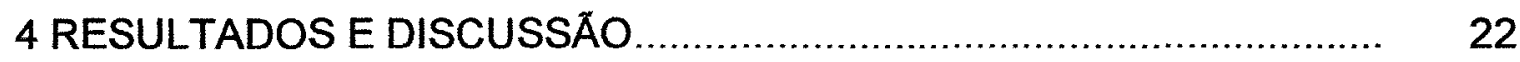

4.1 Produção de matéria seca............................................................... 22

4.2 Número de perfilhos................................................................ 25

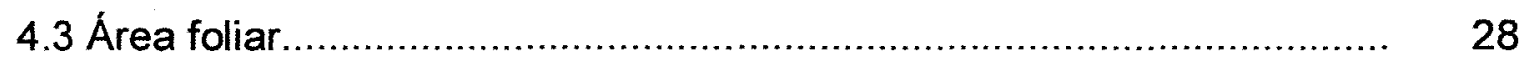

4.4 Atividade da redutase do nitrato................................................... 33

4.5 Estimativa do teor de clorofila através do valor SPAD......................... 35 
4.6 Concentração de nitrogênio na planta................................................ 37

4.6.1 Folhas não-expandidas............................................................ 37

4.6.2 Låminas de folhas novas........................................................... 38

4.6.3 Lâminas de folhas velhas........................................................ 40

4.6.4 Colmos mais bainhas ........................................................... 41

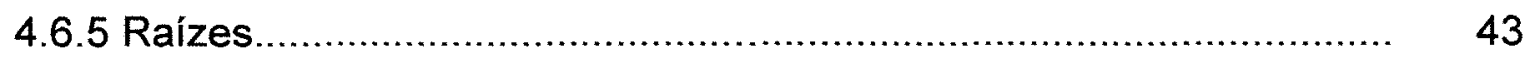

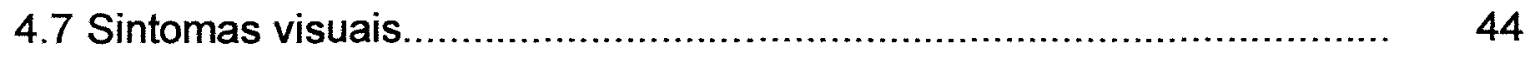

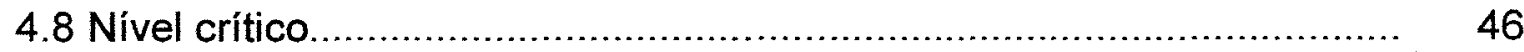

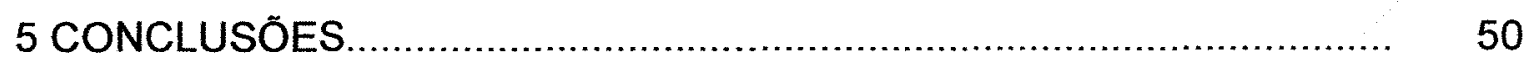

REFERÊNCIAS BIBLIOGRÁFICAS............................................... 51 


\title{
RESPOSTAS FISIOLÓGICAS, BIOQUÍMICA E PRODUTIVAS DO CAPIM-MOMBAÇA A DOSES DE NITROGÊNIO
}

\author{
Autora: Cirlene Aparecida Manarin \\ Orientador: Prof. Dr. Francisco Antonio Monteiro
}

\section{Resumo}

Foi realizado um experimento em casa-de-vegetação, no período de verão, com Panicum maximum Jacq. cultivar Mombaça desenvolvido em solução nutritiva, com doses de nitrogênio e utilizando-se o delineamento experimental de blocos completos ao acaso com quatro repetições. Objetivouse avaliar o efeito do nitrogênio em processos fisiológicos, bioquímico e produtivos, bem como obter informações da concentração do nitrogênio nas partes da planta, relacionando-as à ocorrência de desequilibrio nutricional e ainda, determinar o nivel critico do nitrogênio nessa forrageira, com base na parte selecionada para diagnose.

Estudaram-se oito doses de nitrogênio correspondentes a $0 ; 14 ; 42 ; 126$; 210; 294; 378 e $462 \mathrm{mg} \mathrm{L}^{-1}$ e empregou-se sílica como substrato. Aos 29 dias após o transplante procedeu-se o primeiro corte e o material da parte aérea foi separado em folhas não-expandidas (FNE), lâminas de folhas novas (LN), lâminas de folhas velhas (LV) e colmos mais bainhas $(C+B)$. Aos 26 dias após o primeiro corte, realizou-se a segunda colheita procedendo-se a separação da parte aérea, de acordo com o mesmo critério do primeiro corte. Após o segundo corte das plantas foram separadas as raizes do substrato.

Os resultados mostraram efeitos significativos das doses de nitrogênio na produção de matéria seca da parte aérea e das raízes, no número de perfilhos, 
na área foliar, na atividade da enzima redutase do nitrato nas folhas e na concentração de nitrogênio total da matéria seca da parte aérea e das raízes do capim-Mombaça.

Sintomas visuais de deficiência de nitrogênio puderam ser notados a partir de oito dias após o transplante das plantas para os vasos. Os sintomas de deficiência foram bem visiveis até a dose de nitrogênio de $126 \mathrm{mg} \mathrm{L}^{-1}$ na solução.

A lâmina de folha nova foi considerada a parte mais adequada para a avaliação do estado nutricional em nitrogênio do capim-Mombaça. O nível crítico determinado nesse tecido vegetal foi de 16 a $16,5 \mathrm{~g} \mathrm{~kg}^{-1}$ de nitrogênio e a leitura de valor SPAD correspondente ao nivel crítico foi de 41 a 45 unidades. 


\title{
PHYSIOLOGICAL, BIOCHEMICAL AND YIELD RESPONSES OF MOMBAÇA GRASS TO NITROGEN RATES
}

\author{
Author: Cirlene Aparecida Manarin \\ Adviser: Prof. Dr. Francisco Antonio Monteiro
}

\section{Summary}

An experiment was carried out in greenhouse conditions during Summer season with Panicum maximum Jacq. cv. Mombaça, grown in nutritive solution. Nitrogen rates were tested in the solution, using a complete randomized block design, with four replications. The objective of this study was to evaluate the effects of nitrogen in physiological, biochemical and yield parameters, and to get informations on nitrogen concentration in plant parts and on nitrogen critical level in this forage.

The following eight nitrogen rates were studied: $0,14,42,126,210,294$, 378 and $462 \mathrm{mg} \mathrm{L}^{-1}$. Plants were grown in pots with ground quartz as a substrate. At 29 days after seedlings transplanting to the pots, the first harvest was done and plant tops were separated into non-expanded leaves (NEL), young leaf blades (YLB), old leaf blades (OLB) and culms plus sheaths $(C+S)$. Twenty-six days after the first harvest, the second harvest was done, when plant tops were separated into the same four parts and roots were collected.

The results showed significant effects of nitrogen rates on dry matter yield of plant tops and roots, plant tillering, leaf area, leaf nitrate reductase activity and nitrogen concentration in each plant part sampled in Mombaça grass. 
Visual symptoms of nitrogen deficiency were observed after eigth days of seedling transplanting and were frequent in plants grown in nitrogen rates up to $126 \mathrm{mg} \mathrm{L}^{-1}$.

Young leaf blades are suggested as adequate for Mombaça grass sampling for nitrogen diagnostic purposes. The critical nitrogen levels in such plant tissue were between 16 and $16,5 \mathrm{~g} \mathrm{~kg}^{-1}$ and the SPAD values associated to this critical level were between 41 and 45 . 


\section{INTRODUÇÃO}

A alimentação de ruminantes no Brasil é realizada prioritariamente através de pastagens, nas quais predominam as gramineas. Dentre as gramíneas empregadas na pecuária brasileira, a espécie Panicum maximum Jacq. tem ocupado sempre lugar de destaque, especialmente em áreas com solos de boa fertilidade natural. $O$ interesse dos pecuaristas por plantas pertencentes ao gênero Panicum tem se mantido ao longo dos anos e, por vezes, até incrementado, pelo seu potencial de alta produção de matéria seca por unidade de área e pela sua qualidade nutricional para os animais.

Em razão da importância das forrageiras do gênero Panicum, apreciáveis esforços e quantidade de recursos têm sido gastos em programas de melhoramento e seleção dessas plantas, o que tem resultado em número expressivo de novos cultivares liberados para o mercado consumidor em anos recentes, como são os casos dos capins Tobiatã, Centenário, Aruana, Vencedor, Tânzania e Mombaça. Este é o de mais recente lançamento no mercado, dentro desse gênero de plantas.

A fertilidade do solo utilizado na exploração da pastagem seguramente é um dos principais fatores que interfere tanto no nível de produtividade como na qualidade da forragem. Assim sendo, a correção na disponibilidade de macronutrientes e micronutrientes, bem como na proporcionalidade entre eles, assume importância fundamental no processo produtivo das pastagens.

Uma série ampla de trabalhos de pesquisa têm demonstrado que o suprimento de nitrogênio é o fator de maior impacto tanto na produtividade da planta forrageira bem estabelecida, como na dos animais que a utilizam. Sabe- 
se que esse nutriente é um constituinte essencial de proteínas, ácidos nucléicos, hormônios e clorofila, dentre outros compostos orgânicos imprescindiveis para as plantas.

Para apreciável número de espécies, entre as quais algumas forrageiras, existem estudos relativos à identificação de parte diagnóstica para fins nutricionais, à determinação do nivel crítico, além de respostas fisiológicas e bioquímicas ao suprimento de nitrogênio. Entretanto, para o capim-Mombaça essas informações são escassas na literatura.

Os objetivos desse trabalho com suprimento de nitrogênio para o capimMombaça foram de avaliar nessa forrageira: as respostas em perfilhamento e produtividade da parte aérea e raízes; as variações na leitura da estimativa do teor de clorofila pelo clorofilômetro e na atividade da redutase no nitrato; as oscilações na concentração de nitrogênio em tecidos amostrados na parte aérea do capim e a possibilidade de definir o nivel critico de nitrogênio no tecido amostrado na forrageira. 


\section{REVISÃO DE LITERATURA}

\subsection{Panicum maximum Jacq. cultivar Mombaça}

A espécie de gramínea Panicum maximum Jacq. tem muitos cultivares, dentre eles o mais conhecido e difundido no Brasil é o capim-Colonião. É uma das gramíneas forrageiras que ocupa expressiva quantidade de área nas pastagens do país.

Essa espécie já ocupou área superior a seis milhões de hectares no Brasil, e provavelmente hoje essa área é menor, pois problemas de manejo dos pastos e de fertilidade do solo têm prejudicado tão ampla ocupação de área nas pastagens brasileiras (Aronovich, 1995). É certo porém, que essa espécie continua tendo grande importância, especialmente nas áreas utilizadas para pastejo com gado de corte.

O Panicum maximum tem constantemente mostrado alta produção de matéria seca e boa tolerância a pragas e doenças, além de apresentar alto valor nutritivo (Vallejos et al., 1989).

O local de origem do Panicum maximum é a África Tropical e a introdução no Brasil não está bem documentada. Aronovich (1995) descreveu que, possivelmente na época da escravatura, quando esse capim era utilizado como cama para os escravos nas embarcações vindas da África, ocorreu a chegada da espécie no pais, que se alastrou inicialmente nos locais onde os barcos eram descarregados. A partir daí, se distribuiu e se adaptou tão bem, que atualmente é considerado como nativo em muitas regiões do país. 
A busca por materiais genéticos superiores para gramíneas forrageiras tropicais é uma prática que foi incrementada nos anos 80 e como conseqüência foram lançados os primeiros cultivares de Panicum maximum resultantes desses trabalhos de melhoramento genético e/ou seleção realizados no Brasil (Jank, 1995).

Os cultivares Centenário e Centauro foram lançados pelo Instituto Agronômico (IAC), respectivamente, em 1986 e 1988. Em 1989, o Instituto de Zootecnia (IZ) pré lançou o cultivar Aruana. O Centro de Pesquisa Agropecuária dos Cerrados (CPAC) lançou o cultivar Vencedor em 1990. O Centro Nacional de Pesquisa de Gado de Corte (CNPGC), em conjunto com diversas instituições, lançou os cultivares Tanzânia-1 e Mombaça, respectivamente em 1990 e 1993. Estes dois últimos são resultado da seleção direta do germoplasma de ORSTOM-França, coletado na Tanzânia (Jank, 1995).

De acordo com a EMBRAPA-CNPGC (1993), o capim-Mombaça é uma planta cespitosa, que chega a atingir cerca de $1,65 \mathrm{~m}$ de altura e tem folhas quebradiças com até $3,0 \mathrm{~cm}$ de largura. Em latitude de aproximadamente $21^{\circ} \mathrm{S}$ esse cultivar floresce apenas uma vez por ano, no mês de abril. O cultivar Mombaça produziu $130 \%$ mais matéria seca que o cultivar Colonião e $28 \%$ mais que o cultivar Tanzânia-1, em parcelas sob cortes manuais. No período das secas produziu $11 \%$ da produção anual e apresentou $82 \%$ de folhas durante o ano, produzindo $33 \mathrm{Mg} \mathrm{ha}^{-1}$ ano $^{-1}$ de matéria seca foliar, resultados esses semelhantes aos do cultivar Tanzânia-1, mas muito superiores aos do cultivar Colonião. O cultivar Mombaça revelou-se medianamente resistente à cigarrinha Zulia entreriana. Estima-se também, que a capacidade de suporte desse cultivar seja 2,3 UA ha ${ }^{-1}$. Tal qual a maioria dos cultivares de Panicum maximum o cultivar Mombaça é exigente em fertilidade do solo para um bom e rápido estabelecimento, assim como para cobertura total do solo. Os resultados disponiveis mostram que o cultivar Mombaça é mais eficiente que o cultivar Tanzânia na utilização do fósforo do solo. Quanto à saturação por bases a faixa mais adequada de produtividade tem sido encontrada entre 30 e $45 \%$. 
Jank (1995) constatou que o capim-Mombaça foi $8 \%$ mais produtivo que o capim-Tobiată, até então o cultivar de Panicum mais produtivo no mercado. Segundo essa autora, o Mombaça por ser de porte mais alto e de maior produção, poderá ter muito êxito em sistemas de pastejo intensivo e rotacionado, com deposição de nutrientes.

De sete acessos avaliados em pequenas parcelas com animais na EMBRAPA-CNPGC, o cultivar Mombaça e o acesso BRA-007102 foram superiores às testemunhas Panicum maximum cultivar Tobiatã e Brachiaria brizantha cultivar Marandu, quanto à capacidade de suporte e produção por animal (Euclides et al., 1995).

Machado et al. (1997), avaliando oito genótipos de Panicum maximum Jacq. (Aruana, Centenário, Colonião, K249, KK8, Mombaça, Tanzânia e Tobiatã), submetidos a duas alturas de corte $(20$ e $40 \mathrm{~cm})$, obtiveram resultados mostrando que em ambas as alturas o capim-Mombaça foi um dos mais produtivos.

Em um experimento realizado para avaliação de produção de matéria seca das gramíneas forrageiras Brachiaria decumbens, Brachiaria brizantha e Panicum maximum cv. Mombaça foi constatada maior produção pela Brachiaria decumbens seguida por capim-Mombaça e Brachiaria brizantha (Pacheco et al.,1996).

É necessário o conhecimento do comportamento de cultivares de lançamento mais recente, com relação às exigências e características produtivas, pois, para manter-se a produtividade da espécie é necessária a reposição adequada dos nutrientes (Paulino et al., 1998).

\subsection{Nitrogênio e produção de matéria seca da forrageira}

O nitrogênio é um dos mais abundantes nutrientes no material das plantas secas. Ele é um constituinte essencial das proteínas, ácidos nucléicos, 
hormônios, clorofila e de uma variedade de outros componentes (Hopkins, 1995).

As gramineas tropicais, particularmente as do grupo $\mathrm{C} 4$, têm alta capacidade fotossintética, usam água eficientemente, e respondem ao suprimento de nitrogênio com alta taxa de crescimento. Essas plantas podem absorver nitrogênio eficientemente tanto sob a forma de nitrato como sob a forma de amônio. Pastagens de gramíneas tropicais, quando fertilizadas com apreciável dose de nitrogênio, alcançam uma produção de carne por unidade de área superior a que atingem quando em consorciação com leguminosas (Fernandes \& Rossiello, 1986).

O nitrogênio uma vez absorvido pelas plantas é reduzido à forma amoniacal e combinado nas cadeias orgânicas do vegetal, formando ácido glutâmico e a partir daí os aminoácidos. Estudos têm demonstrado que essa assimilação é limitada no processo de redução do nitrato a amônia, processo em que a redutase do nitrato é a enzima-chave (Rufty et al., 1986).

$O$ acúmulo de nitrato em plantas alimentícias e em forragens tem importância particular para os ruminantes: o nitrato pode ser reduzido a nitrito no tubo digestivo, pelos microrganismos lá existentes; esse nitrito se combina com a hemoglobina do sangue para produzir a metahemoglobina, a qual não pode funcionar como transportador de oxigênio e o animal sofre a deficiência de oxigênio no seu organismo como um todo (Malavolta, 1980).

Sanzonowicz (1986) relatou que, em pastagens estabelecidas há cinco ou mais anos e que receberam a adubação recomendada pelo Centro de Pesquisas Agropecuárias do Cerrado (CPAC), foi observado que o principal nutriente limitante das pastagens de Brachiaria ruziziensis e Brachiaria decumbens era o nitrogênio.

Uma série de experimentos têm demonstrado que incrementos significativos na produção de matéria seca e no valor nutritivo de Panicum maximum podem ser obtidos com o emprego de nitrogênio. Apesar de na maioria desses experimentos ter havido respostas lineares de produção de 
matéria seca às doses de nitrogênio, a magnitude dessas respostas tem sido variável (Colozza, 1998).

Monteiro \& Werner (1977), aplicando $150 \mathrm{~kg} \mathrm{ha}^{-1}$ ano $^{-1}$ de nitrogênio em uma área estabelecida com capim-Colonião, obteve resultados significativos no aumento da produção de matéria seca durante o ano. Foram avaliados cinco períodos de crescimento durante todo o ano e constatou-se que a taxa de crescimento do capim, na média dos períodos, aumentou de 14,36 para 31,23 $\mathrm{kg} \mathrm{MS} \mathrm{ha}^{-1} \mathrm{dia}^{-1}$, em consequência da adubação.

Favoretto et al. (1995), trabalhando com três doses de nitrogênio $(0 ; 75$ e $150 \mathrm{~kg} \mathrm{ha}^{-1}$ ), constataram que a maior produção de matéria seca total e de folhas verdes do capim-Colonião ocorreu com a aplicação da mais alta dose utilizada.

Barbosa et al. (1998), estudando o crescimento de folhas no capimMombaça submetido a duas doses de nitrogênio e quatro intervalos entre cortes, obtiveram resultado positivo para aplicação de nitrogênio, que proporcionou aumentos lineares no número de folhas e na expansão foliar.

Hoffmann (1992) constatou aumentos significativos na produção de matéria seca de parte aérea do Panicum maximum cultivar $\mathrm{Z}-1$, cultivado em latossolo vermelho escuro tratado com $0 ; 100 ; 200 ; 300$ e $500 \mathrm{mg} \mathrm{kg}^{-1}$ de nitrogênio, sendo que a máxima produção foi obtida com nitrogênio em 338 $\mathrm{mg} \mathrm{kg}^{-1}$, para o primeiro crescimento.

A recomendação para aplicação de nitrogênio em pastagens de Panicum maximum citada por Monteiro (1995) tem variado de 50 a $300 \mathrm{~kg} \mathrm{ha}^{-1}$ ano-1, sendo que a dose mais baixa tem sido considerada mínima para evitar a degradação da forragem e as mais elevadas são destinadas ao incremento na produtividade e para explorações mais intensivas da forrageira. Salientou ainda o autor a necessidade de parcelamento da adubação quando se aplicam as doses mais elevadas do fertilizante. 
Santos et al. (1995) observaram que o capim-Vencedor submetido a doses de nitrogênio atingiu o máximo rendimento de matéria seca da parte aérea com a dose de $362 \mathrm{mg} \mathrm{L}^{-1}$ na solução nutritiva.

A produção de matéria seca, tanto da parte aérea como das raízes, da Brachiaria decumbens Stapf variou significamente com as doses de nitrogênio na solução. As máximas produções da parte aérea no primeiro e no segundo crescimentos foram obtidas nas doses de nitrogênio de 435 e $433 \mathrm{mg} \mathrm{L}^{-1}$ de solução, respectivamente. A máxima produção de matéria seca das raizes da braquiária foi alcançada com nitrogênio na solução de $453 \mathrm{mg} \mathrm{L}^{-1}$ (Santos, 1997).

Corrêa et al. (1998), estudando duas doses de nitrogênio (200 e 400 $\mathrm{kg} \mathrm{ha}^{-1}$ ) e frequência de cortes na produção de matéria seca em doze gramíneas forrageiras, entre elas, o Panicum maximum cultivar Mombaça, verificaram efeito positivo das doses de nitrogênio na produção de matéria seca. Constataram também que a diminuição na produção por corte em função do aumento da frequência de cortes foi em parte compensada pelo número de colheitas, visto que, doses elevadas de nitrogênio aceleram o desenvolvimento das plantas, proporcionando maior frequência de cortes e/ou ciclos de pastejo.

Colozza (1998), testando a influência do nitrogênio no capim-Mombaça em experimento de casa-de-vegetação e utilizando como substrato latossolo vermelho-amarelo distrófico, obteve pontos de máxima produção de matéria seca com o emprego de nitrogênio de 147 e $294 \mathrm{mg} \mathrm{kg}^{-1}$ de solo, respectivamente para o primeiro e segundo períodos de crescimento.

\subsection{Perfilhamento}

Perfilho ou afilho é a unidade vegetativa básica das gramíneas e a perenidade das gramíneas forrageiras é garantida pela sua capacidade em rebrotar após cortes ou pastejos sucessivos. O número e 0 tamanho dos perfilhos têm sido usados para analisar o crescimento dos capins (Rodrigues \& Reis, 1995). O conhecimento da dinâmica de aparecimento de perfilhos após o 
corte é de grande utilidade para o manejo racional de cultivares de gramíneas forrageiras (Barbosa et al., 1998).

O número de perfilhos pode ser reduzido por estresse hídrico, elevação na temperatura, redução na quantidade de luz ou desfolhação parcial. A estação do ano e a nutrição mineral também afetam a taxa de perfilhamento em Panicum maximum (Costa, 1990; Cecato, 1993).

Langer (1963) enfatizou que o nitrogênio é o nutriente mais importante para o perfilhamento de gramíneas estabelecidas, visto que, em condições de deficiência desse nutriente, o número de perfilhos na planta é significativamente diminuído.

Werner (1986) relatou que o nitrogênio é responsável pelo crescimento de gramíneas, sendo o nutriente que se esgota mais facilmente nos solos, tendo influência direta no desenvolvimento dos perfilhos, entre outros parâmetros.

O aumento na produção de matéria seca, taxa de crescimento diário e densidade de perfilhos, com as doses de nitrogênio, foi relatado por Herling et al. (1995), em experimento utilizando dois cultivares de Panicum maximum (Colonião e Centenário). A eficiência de utilização do nitrogênio foi aumentada com o incremento nas doses desse nutriente.

Estudando os efeitos de doses de nitrogênio na solução nutritiva em três gramíneas forrageiras, Corrêa (1996) observou que o incremento do nitrogênio no substrato proporcionou aumento no perfilhamento dos cultivares Colonião, Tanzânia-1 e Vencedor de Panicum maximum.

Santos(1997), avaliando as respostas do capim-braquiária cultivada em casa-de-vegetação, tendo sílica como substrato e utilizando doses de nitrogênio de $0 ; 14 ; 42 ; 126 ; 210 ; 294 ; 378$ e $462 \mathrm{mg} \mathrm{L}^{-1}$ de solução nutritiva, obteve resultados que demonstraram o efeito significativo no número de perfilhos por vaso, com o aumento da dose do nutriente, tanto no primeiro como no segundo crescimento do capim. 
A dinâmica de perfilhamento no capim-Mombaça submetido a duas doses de nitrogênio ( 0 e $400 \mathrm{~kg} \mathrm{ha}^{-1}$ ) aplicadas em cobertura e na forma de uréia, foi estudada por Barbosa et al. (1998). Observaram que o nitrogênio apresentou efeito marcante na sobrevivência de perfilhos, tanto nos basais como nos aéreos, e no comportamento de perfilhamento desta forrageira. $\mathrm{Na}$ presença de nitrogênio esse cultivar apresentou maiores quantidades de ambos os tipos de perfilhos, quando comparado ao tratamento sem nitrogênio.

O número de perfilhos no capim-Mombaça foi significativamente influenciado pelas doses de nitrogênio, aumentando até as doses de 149 e 268 $\mathrm{mg} \mathrm{kg}{ }^{-1}$, respectivamente para o primeiro e segundo períodos de crescimento no experimento de Colozza (1998).

\section{4 Área foliar do capim-Mombaça}

Uma vez que os herbivoros se alimentam das partes verdes das plantas, a disponibilidade de forragem deve ser entendida como a biomassa aérea viva acumulada durante o processo de crescimento das plantas que compõem a pastagem. Se as condições ambientais permanecem num nível ótimo, o processo de acúmulo é contínuo e constante enquanto não ocorrer senescência das partes mais antigas das plantas (Nabinger, 1997).

Numa pastagem em crescimento vegetativo na qual aparentemente apenas folhas são produzidas (pois ainda não há alongamento dos entrenós) a morfogênese pode ser descrita por três características básicas: taxa de surgimento de folhas, taxa de alongamento das folhas e duração de vida da folha (Chapman \& Lemaire, 1993). Essas características são determinadas geneticamente, mas podem ser influenciadas por variáveis ambientais como temperatura e disponibilidade hídrica e de nutrientes.

A disponibilidade de nitrogênio tem pronunciado efeito na taxa de alongamento das folhas, podendo resultar em valores três a quatro vezes 
menores num alto nivel de deficiência, quando comparado a um nivel não limitante (Gastal et al., 1992).

Dentre os fatores limitantes ao índice de área foliar (IAF) a deficiência de nitrogênio e de água são os mais universais. Tanto a deficiência de nitrogênio como de água diminuem progressivamente a taxa fotossintética das folhas, a eficiência de conversão, a interceptação da luz, a produção de biomassa e o índice de área foliar (Nabinger, 1997).

\subsection{Atividade da redutase do nitrato}

As formas de nitrogênio mais absorvidas pelas plantas são o nitrato e o amônio. O nitrato é usualmente a forma predominantemente absorvida e é necessário que ocorram transformações do nitrato na planta para que o mesmo possa ser metabolizado pelo vegetal (Mengel \& Kirkby, 1987).

A primeira reação de redução do nitrato na planta é catalisada pela redutase do nitrato, que é amplamente distribuída nas plantas, e muito importante no processo de formação de proteínas (Lehninger, 1976). A redutase do nitrato é importante no metabolismo da planta e sua atividade está relacionada com a taxa de absorção de nitrato. A atividade da enzima é induzida pelo substrato e, de alguma forma, relacionada ao rendimento de matéria seca e à concentração de proteína na planta (Santos, 1997).

$A$ atividade da redutase do nitrato em plantas é uma boa estimativa do estado nutricional quanto ao nitrogênio e tem boa correlação com o crescimento e produção, porém esta atividade é também influenciada por outros fatores (Srivastava, 1980).

Shen et al. (1993), estudando a colza (Brassica napus L.), concluiram que a atividade da redutase do nitrato foi incrementada com o fornecimento de nitrogênio no solo.

Andrade (1994), trabalhando com capim-Colonião e proporções de fornecimento de amônio:nitrato, observou que a atividade "in vitro" da redutase 
do nitrato aumentou significativamente quando foram fornecidas ambas as fontes de nitrogênio indicando certa ação estimulatória do íon amônio na atividade da enzima.

Estudando doses de nitrogênio e magnésio e as influências em aspectos produtivos e bioquímicos dos capins Colonião, Tanzânia-1 e Vencedor, Corrêa (1996) verificou que a atividade da enzima redutase do nitrato nas folhas de Panicum maximum aumentou com as doses de nitrogênio independente da dose de magnésio utilizada na solução nutritiva.

A elevação das doses de nitrato na solução nutritiva resultou em aumentos significativos na atividade da redutase do nitrato na folha dos capins estudados, (Panicum maximum cultivar Tanzânia-1, Brachiaria brizantha cultivar Marandu e Melinis minutiflora), com diferenças efetivas entre as três doses de nitrato empregadas (Abreu, 1994).

\subsection{Estimativa do teor de clorofila através do valor SPAD}

A clorofila é um parâmetro informativo apropriado para a estimativa de nitrogênio absorvido sob várias condições de crescimento, como temperatura, umidade de solo e intensidade luminosa. O medidor de clorofila SPAD-502 desenvolvido pela Minolta no Japão fornece leituras em unidades "SPAD" que correspondem ao teor do pigmento presente na folha. $O$ instrumento tem sido usado para estimar a concentração de nitrogênio da folha, visto que a clorofila e o nitrogênio se correlacionam positivamente. Há, ainda, algumas vantagens no uso deste medidor, como ser portátil e de fácil manuseio, possibilitar economia de tempo e dinheiro (já que não há necessidade de mandar as amostras ao laboratório) diagnóstico prévio de possível falta de nitrogênio podendo-se prevenir severas deficiências, além de ser uma técnica não destrutiva, e podese amostrar tantas vezes quantas forem necessárias, sem a destruição do limbo foliar (Minolta Camera Co., 1989). 
Vários trabalhos realizados recentemente têm demonstrado o potencial para utilização do medidor de clorofila SPAD-502 para estimar de modo conveniente o nivel de nitrogênio das plantas, proporcionando melhor manejo da adubação nitrogenada. Porém, a maior parte dos resultados disponíveis refere-se às grandes culturas, como as de milho e arroz (Lima Filho et al., 1997).

Ainda são escassas as informações de pesquisas correlacionando os resultados das leituras do clorofilômetro com a concentração de nutrientes e o rendimento das diversas culturas (Santos, 1997).

Trabalhos correlacionando valores de leitura SPAD com respostas fisiológicas e produtivas de gramíneas forrageiras são ainda mais raros. Há necessidade de maior precisão na questão da aplicação dos nutrientes, haja vista a preocupação com diversos fatores desde econômicos até ambientais. Portanto, é de extrema importância que se tenha formas simples e seguras de se avaliar as necessidades de suprimento de nutrientes para as culturas.

A concentração de nitrogênio no tecido vegetal correlaciona-se significativamente com as leituras do aparelho clorofilometro. Furlani Jr. et al. (1996), estudando a cultura do feijoeiro, concluíram que significativas correlações ocorreram entre as leituras SPAD e as doses de nitrogênio, bem como entre as leituras SPAD e as concentrações de nitrogênio nas folhas.

Os resultados das leituras de clorofila obtidos através do clorofilômetro SPAD-502, nas lâminas foliares do capim-braquiária estudadas por Santos (1997), apresentaram altos coeficientes entre as leituras do clorofilômetro e as doses de nitrogênio fornecidas no primeiro (coeficiente igual a 0/90) e no segundo (coeficiente igual a 0,99 ) crescimento. $O$ teor de clorofila expresso em valor SPAD, no primeiro e no segundo crescimento da forragem variou entre 17,0 e 50,2 e 23,9 e 52 para condição de omissão e as doses do nutriente para máximo valor SPAD, que foram 330 e $442 \mathrm{mg} \mathrm{L}^{-1}$, respectivamente. Esse mesmo autor concluiu que o nível crítico de nitrogênio está entre valores de SPAD de 37 a 49. 
É necessário o conhecimento do comportamento de cultivares de lançamento mais recente, com relação às exigências e características produtivas. Paulino et al. (1998) concluíram que as leituras SPAD realizadas em condições de campo podem identificar prontamente severas deficiências de nitrogênio em Panicum maximum e que leituras abaixo de 38 unidades de SPAD em folhas recém-expandidadas são indicativos de estado nutricional inadequado.

Colozza (1998), estudando o capim-Mombaça cultivado em latossolo vermelho-amarelo em condições de casa-de-vegetação,concluiu que as lâminas de folhas novas mostraram-se mais adequadas para avaliação do estado nutricional em nitrogênio para este capim. Os valores SPAD correspondentes aos níveis críticos de nitrogênio estiveram entre 32,0 e 38,6 unidades SPAD, para valores de níveis críticos de nitrogênio total de 20,8 e $22,9 \mathrm{~g} \mathrm{~kg}^{-1}$ para o primeiro e segundo crescimento, respectivamente.

\subsection{Amostragem de tecido vegetal e nível crítico}

Para um perfeito desenvolvimento de uma cultura com altas produções, explorando-se ao máximo o potencial genético da espécie, é necessário que esta esteja equilibrada fisiologicamente e nutrida com todos os nutrientes supridos em proporções adequadas.

A falta ou excesso de um dado elemento mineral desencadeia uma série de eventos sucessivos como: lesão molecular, alteração subcelular, modificação celular e alteração no tecido (Malavolta et al., 1994). Dentro de limites, existe uma relação direta entre a concentração de um elemento no tecido vegetal e o crescimento ou produção da planta. Em geral, a composição da folha é a que melhor reflete o estado nutricional da planta.

O nível crítico fisiológico para um dado nutriente é o limite de concentração abaixo do qual há uma diminuição no crescimento ou na produção da planta. O nível crítico superior, por outro lado, corresponde a 
valores acima dos quais há também uma queda no crescimento ou na produção devido ao desequilibrio ou a toxicidade do nutriente, conforme Malavolta et al., (1997). Estes autores consideraram como nivel crítico inferior a concentração do nutriente que reduz em $10 \%$ a produção máxima e como nivel crítico superior a concentração tóxica do nutriente na mesma proporção de redução da produção máxima do vegetal.

Santos (1995) concluiu que as lâminas de folhas novas apresentaram os maiores coeficientes de correlações entre a concentração de nitrogênio no tecido e a produção de matéria seca da parte aérea, devendo ser o componente utilizado para avaliação do estado nutricional em nitrogênio no capimbraquiária. Acrescentou ainda que o nivel crítico desse nutriente nessa forrageira está entre 14,5 e $22,0 \mathrm{~g} \mathrm{~kg}^{-1}$ de matéria seca.

Colozza (1998) relatou que para o capim-Mombaça as lâminas de folhas novas mostraram-se mais adequadas para avaliação do estado nutricional em nitrogênio e que o nível crítico desse nutriente está entre 20,8 e $22,9 \mathrm{~g} \mathrm{~kg}^{-1}$ de matéria seca. 


\section{MATERIAL E MÉTODOS}

\subsection{Localização, época e gramínea}

O experimento foi conduzido na casa-de-vegetação localizada no Departamento de Solos e Nutrição de Plantas, da Escola Superior de Agricultura "Luiz de Queiroz"; ESALQ/USP, Piracicaba, Estado de São Paulo. O período de cultivo das plantas estendeu-se de janeiro até março de 1999. A gramínea estudada foi o Panicum maximum cultivar Mombaça.

\subsection{Doses de nutrientes, soluções nutritivas e delineamento experimental}

Foram utilizadas oito doses de nitrogênio na solução nutritiva, sendo as seguintes: $0 ; 14 ; 42 ; 126 ; 210 ; 294 ; 378$ e $462 \mathrm{mg} \mathrm{L}^{-1}$. As soluções foram preparadas a partir daquela proposta por Sarruge (1975), devidamente modificada para satisfazer o suprimento de nitrogênio. Na Tabela 1 são apresentadas as soluções estoques empregadas, bem como os respectivos volumes utilizados na preparação das soluções nutritivas. As soluções foram idênticas às utilizadas por Santos (1997) em experimentos com outros capins.

O delineamento experimental foi em blocos completos ao acaso, com oito doses e quatro repetições. A fim de assegurar a obtenção de material vegetal na quantidade minima necessária para as determinações nos tecidos amostrados na parte aérea das plantas, principalmente nas mais baixas doses de nitrogênio, duplicou-se todo o experimento. Assim foram empregados um total de 64 vasos. 
Tabela 1 Mililitros das soluções estoque empregados no preparo de cada litro das soluções nutritivas para as doses de nitrogênio estudadas.

\begin{tabular}{|c|c|c|c|c|c|c|c|c|c|c|}
\hline \multirow{2}{*}{\multicolumn{2}{|c|}{$\begin{array}{l}\text { Solução } \\
\text { estoque }\end{array}$}} & \multicolumn{9}{|c|}{ Dose de nitrogênio $\left(\mathrm{mg} \mathrm{L}^{-1}\right)$} \\
\hline & & 0 & & 4 & 42 & 126 & 210 & 294 & 378 & 462 \\
\hline $\mathrm{KNO}_{3}$ & $1 \mathrm{~mol} \mathrm{~L}^{-1}$ & - & 1 & & 3 & 5 & 5 & 5 & 5 & 5 \\
\hline $\mathrm{Ca}\left(\mathrm{NO}_{3}\right)_{2}$ & $1 \mathrm{~mol} \mathrm{~L}^{-1}$ & - & - & & - & - & 5 & 5 & 5 & 5 \\
\hline $\mathrm{NH}_{4} \mathrm{NO}_{3}$ & $1 \mathrm{~mol} \mathrm{~L}^{-1}$ & - & - & & |- & 2 & - & 3 & 6 & 9 \\
\hline $\mathrm{KH}_{2} \mathrm{PO}_{4}$ & $1 \mathrm{~mol} \mathrm{~L}^{-1}$ & 1 & & & 1 & 1 & 1 & 1 & 1 & 1 \\
\hline $\mathrm{KCl}$ & $1 \mathrm{~mol} \mathrm{~L}^{-1}$ & 5 & te & & 2 & - & - & - & - & - \\
\hline $\mathrm{CaCl}_{2}$ & $1 \mathrm{~mol} \mathrm{~L}^{-1}$ & 5 & & & 5 & 5 & - & - & - & - \\
\hline $\mathrm{MgSO}_{4}$ & $1 \mathrm{~mol} \mathrm{~L}^{-1}$ & 2 & & & 2 & 2 & 2 & 2 & 2 & 2 \\
\hline Micro-Fe ${ }^{*}$ & & 1 & & 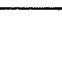 & 1 & 1 & 1 & 1 & 1 & $\sqrt{1}$ \\
\hline $\mathrm{Fe}-\mathrm{EDTA}^{* *}$ & & 1 & & 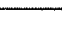 & 1 & 1 & 1 & 1 & 1 & 1 \\
\hline
\end{tabular}

* $A$ solução de micronutrientes teve a seguinte composição $\left(\mathrm{g} \mathrm{L}^{-1}\right): \mathrm{H}_{3} \mathrm{BO}_{3}=$ 2,86; $\mathrm{MnCl}_{2} \cdot 4 \mathrm{H}_{2} \mathrm{O}=1,81 ; \mathrm{ZnCl}_{2}=0,10 ; \mathrm{CuCl}_{2}=0,04$ e $\mathrm{H}_{2} \mathrm{MoO}_{4} \cdot \mathrm{H}_{2} \mathrm{O}=0,02$.

** Dissolveram-se $26,1 \mathrm{~g}$ de EDTA dissódico em $286 \mathrm{~mL}$ de $\mathrm{NaOH}$ mol L ${ }^{-1}$, misturando-se com $24,0 \mathrm{~g}$ de $\mathrm{FeSO}_{4} .7 \mathrm{H}_{2} \mathrm{O}$, arejando-se por uma noite e completando-se a $1 \mathrm{~L}$ com água desionizada.

\subsection{Instalação e condução do experimento}

Como meio de crescimento da forrageira foram utilizados vasos plásticos de 3,6 L, preenchidos com sílica. Esse substrato foi lavado com água de torneira e água desionizada.

As sementes do capim foram colocadas para germinar em bandejas plásticas contendo areia lavada em água corrente e, em seguida, em água desionizada. Após 13 dias da semeadura foram transplantadas 15 mudas com cerca de $5 \mathrm{~cm}$ de altura para cada vaso. Após o transplante foi adicionado um 
litro de solução diluída a $30 \%$ da concentração total correspondente a cada dose estudada. Durante os primeiros dias procederam-se desbastes periódicos até permanecerem cinco plantas por vaso nos blocos identificados com números pares, e seis plantas por vaso nos blocos ímpares. Essa distinção foi utilizada a fim de assegurar a obtenção de material vegetal para a realização da análise da redutase do nitrato no tecido amostrado na parte aérea das plantas, sem alterar os resultados posteriores, já que esta determinação incluiu a perda do material vegetal.

A solução nutritiva foi mantida nos vasos durante o dia e drenada à noite. A solução foi circulada através da sílica duas vezes em cada dia e foi trocada 15 dias após o transplante das mudas para os vasos no primeiro período de crescimento e a cada 10 dias após o corte no segundo período de crescimento das plantas. Durante o periodo do experimento, a cada três dias os vasos eram remanejados nas suas posições dentro de cada bloco, como forma de homogeneizar as condições para cada um dos blocos experimentais.

\subsection{Coleta do material vegetal}

Aos 29 dias após o transplante procedeu-se o primeiro corte, a $2 \mathrm{~cm}$ do colo das plantas, e o material da parte aérea foi separado em folhas nãoexpandidas (FNE = folhas do topo da planta, sem lígula visivel), lâminas de folhas novas ( $\mathrm{LN}=$ lâminas das duas folhas mais jovens totalmente expandidas, com lígula visivel), lâminas de folhas velhas (LV = lâminas das demais folhas totalmente expandidas), e em colmos mais bainhas $(C+B=$ colmos propriamente ditos e as bainhas que foram mantidas a ele aderidas). Aos 26 dias após 0 primeiro corte, realizou-se a segunda colheita procedendo-se a separação da parte aérea segundo o mesmo critério descrito para o primeiro corte. As raizes também foram separadas da sílica e lavadas. O material vegetal colhido foi colocado para secar em estufa de circulação forçada de ar à temperatura de $70^{\circ} \mathrm{C}$, até massa constante. 


\subsection{Avaliações no material vegetal}

\subsubsection{Produção de matéria seca e perfilhos}

A produção de matéria seca da parte aérea em cada um dos dois períodos de crescimento do capim foi avaliada através da soma do peso do material seco dos seus componentes (folhas não-expandidas, lâminas de folhas novas, lâminas de folhas velhas e colmos + bainhas). A produção de matéria seca das raizes foi obtida diretamente da pesagem do material seco.

Antes de se proceder a cada corte da forrageira foi realizada a contagem do número de perfilhos presentes em cada vaso. Para efeito dessa contagem o colmo principal (planta-mãe) também foi incluído.

\subsubsection{Atividade da redutase do nitrato}

A determinação da atividade da redutase do nitrato foi realizada segundo metodologia descrita por Mulder et al. (1959). Aos 22 e 20 dias, respectivamente, do primeiro e segundo períodos de crescimento da gramínea, foi efetuada essa determinação em amostras da lâmina da segunda folha completamente expandida (no sentido do ápice para a base da planta). Antes da coleta das lâminas foliares, para que se conseguisse uma padronização e redução da interferência de fatores ambientais na atividade enzimática, as plantas foram colocadas em câmara-de-crescimento para duas horas de exposição à luminosidade constante, em temperatura de $28^{\circ} \mathrm{C}$. As leituras dos extratos foram realizadas em fotocolorímetro a $540 \mathrm{~nm}$ e utilizou-se a reta padrão de nitrito e análise de regressão para cálculo da concentração de nitrito no meio. 


\subsubsection{Estimativa do teor de clorofila através do valor SPAD}

Para a estimativa do teor de clorofila, avaliada em unidade SPAD, foi empregado o clorofilômetro SPAD-502 (Soil-Plant Analysis Development Section, Minolta Camera Co., Osaka, Japan). O aparelho foi utilizado em folhas intactas sendo a leitura correspondente à quantidade de clorofila presente na amostra. Os espectros de absorção são determinados com base na quantidade de luz transmitida pela folha amostrada em dois comprimentos de onda, sendo nas áreas do vermelho aproximadamente em $650 \mathrm{~nm}$ e infravermelho em 940 $\mathrm{nm}$, onde os picos de absorção são máximo e mínimo, respectivamente. Nesta faixa as leituras não são influenciadas pela presença de outros pigmentos. A luz transmitida é convertida em sinais elétricos, que são digitalizados e microprocessados para cálculo em valor SPAD da medida de clorofila (Minolta Camera Co., 1989).

As leituras do clorofilômetro foram realizadas aos 21 e 19 dias do primeiro e segundo crescimentos da forrageira, no terço médio da lâmina da segunda folha completamente expandida a partir do ápice de cada planta. O procedimento foi baseado em estudos anteriores realizados por Santos (1997), que efetuou uma avaliação dos valores de clorofila em unidades SPAD ao longo do comprimento da lâmina foliar e em cada folha da planta. Os resultados, apresentados por esse autor, demonstraram que a parte mediana das folhas (terço médio foliar) revelou melhor estabilidade dos valores SPAD, uma vez que no terço basal da lâmina foliar os valores foram menores e na extremidade das lâminas foram observadas maiores variações nos resultados. $O$ valor representativo de cada unidade experimental foi obtido com a média de dez leituras executadas na lâmina foliar das plantas. 


\subsubsection{Composição mineral do tecido vegetal}

Para obtenção da amostra do material vegetal a ser moída e analisada em laboratório juntaram-se as amostras colhidas nos vasos duplicados de cada dose de nitrogênio, em cada bloco experimental. A moagem das amostras ocorreu em moinho tipo Wiley e elas foram acondicionadas em sacos plásticos. A determinação da concentração de nitrogênio total em cada componente da parte aérea e nas raízes foi efetuada conforme metodologia de Sarruge \& Haag (1974). A digestão utilizada para a obtenção do extrato foi a sulfúrica e a determinação do nitrogênio total envolveu a destilação em aparelho semi-micro Kjeldahl e a titulação, do coletado em solução de ácido bórico mais indicadores, com ácido sulfúrico.

\subsection{Análises estatísticas}

Submeteram-se os resultados à análise de variância e, quando verificada a significância para as doses de nitrogênio, procedeu-se à análise de regressão para os componentes de primeiro e de segundo grau. Os resultados de número de perfilhos tiveram tratamento estatístico como variável descontínua e foram realizadas comparações de médias para esse parâmetro avaliado. Empregou-se o procedimento estatístico "Statistical Analysis System"(SAS-WINDOWS, 1989). 


\section{RESULTADOS E DISCUSSÃO}

\subsection{Produção de matéria seca}

A produção de matéria seca tanto da parte aérea como das raízes do Panicum maximum cultivar Mombaça variou significativamente $(P<0,01)$ com as doses de nitrogênio na solução, no material colhido no primeiro e no segundo corte da forrageira.

A produção da parte aérea da forrageira coletada no primeiro corte respondeu às doses de nitrogênio segundo um modelo quadrático (Figura 1). $O$ ponto de máxima produção ocorreu com a dose de nitrogênio de $447 \mathrm{mg} \mathrm{L}^{-1}$ na solução. Altas respostas de nitrogênio na produção de matéria seca do Panicum maximum cultivar Mombaça foram também relatadas por Colozza (1998) e Costa (1999).

No segundo corte, como ilustrado na Figura 2, a produção de matéria seca da parte aérea também respondeu às doses de nitrogênio segundo um modelo de segundo grau. A máxima produção de matéria seca da parte aérea no segundo corte, foi alcançada com nitrogênio em $433 \mathrm{mg} \mathrm{L}^{-1}$ de solução. 


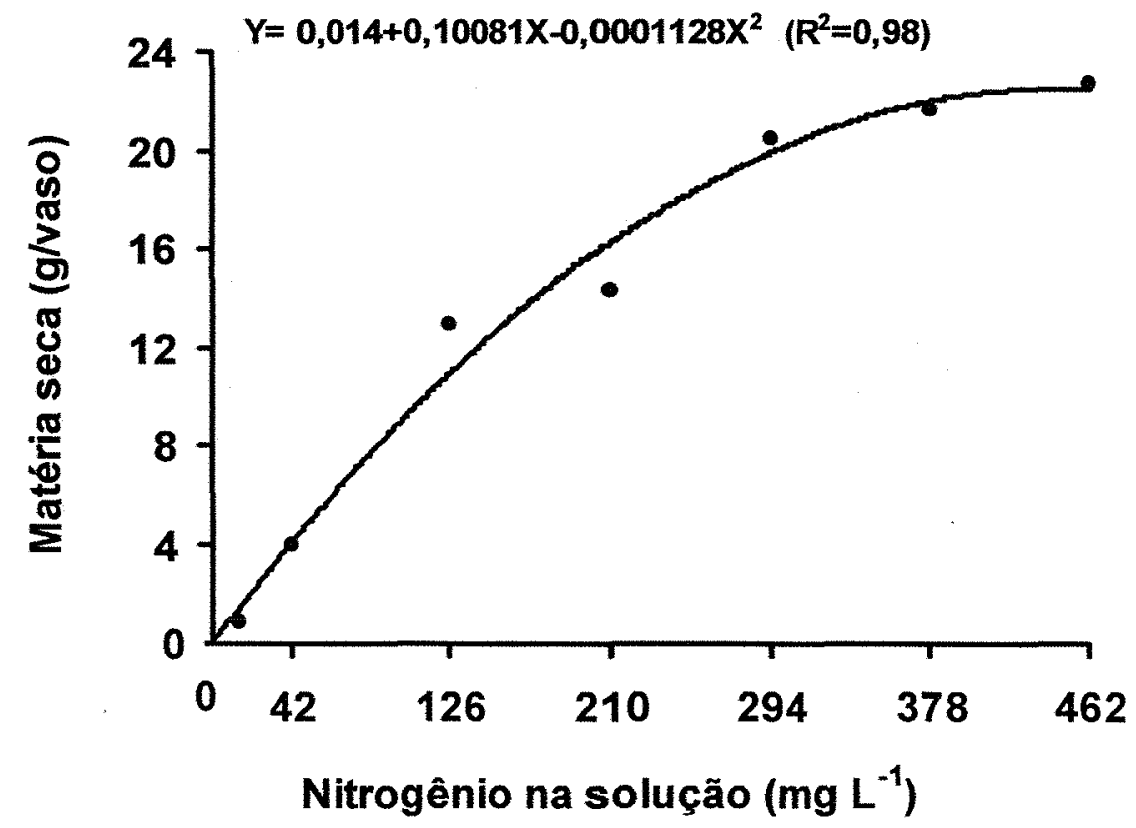

Figura 1. Produção de matéria seca da parte aérea do capim-Mombaça, no primeiro corte, em função das doses de nitrogênio.

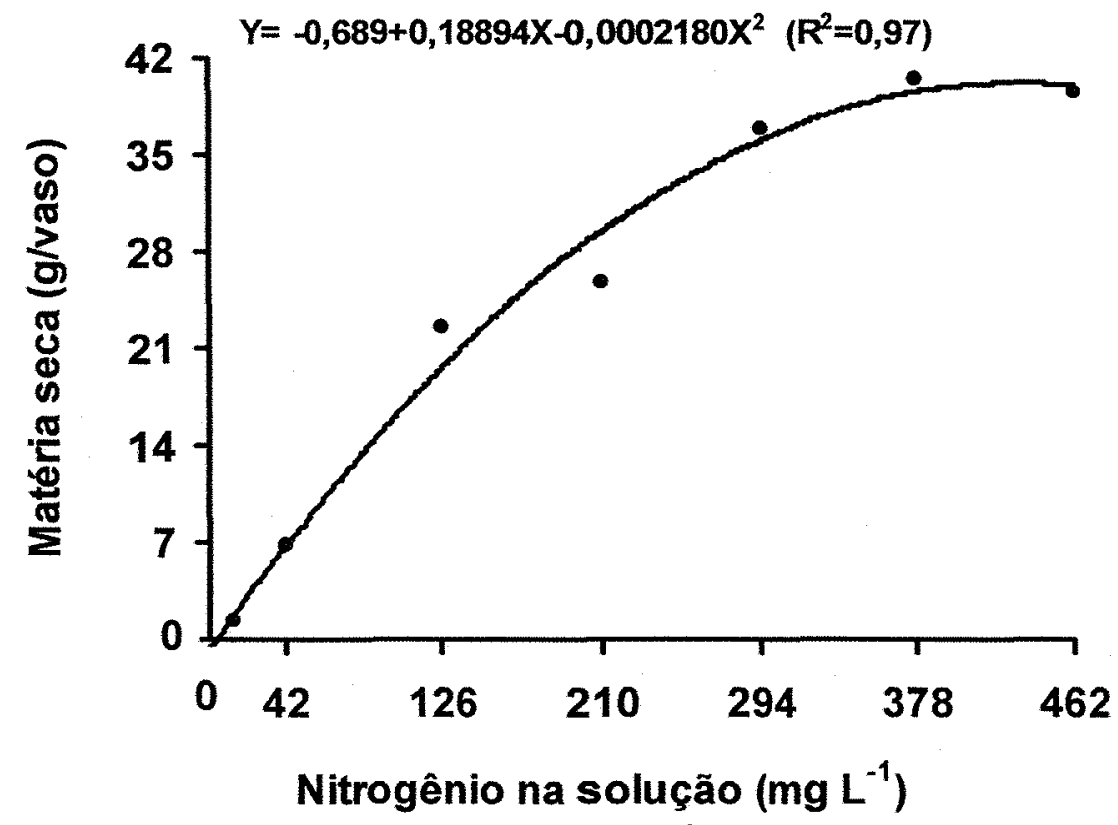

Figura 2. Produção de matéria seca da parte aérea do capim-Mombaça, no segundo corte, em função das doses de nitrogênio. 
As doses de nitrogênio para máxima produção de matéria seca da parte aérea no primeiro e no segundo crescimento neste experimento foram mais elevadas que as obtidas por Santos et al. (1995) e Corrêa (1996) em estudo com o capim-Vencedor. Esses resultados comprovam o potencial produtivo do Panicum maximum cultivar Mombaça, conforme apontado por Jank (1995).

Corrêa (1996), estudando três cultivares de Panicum maximum, relatou a importância do suprimento de nitrogênio para os incrementos na produção de matéria seca desses cultivares, observando ainda que os capins Vencedor, Colonião e Tanzânia-1 têm potencial para responder a doses elevadas de nitrogênio no substrato. Esses resultados demonstram a necessidade de estudos para adequação do fornecimento de nitrogênio para as gramíneas forrageiras.

Ferragine (1998) obteve máximas produções de matéria seca da parte aérea, no primeiro e no segundo corte da Brachiaria decumbens Stapf, com o suprimento de nitrogênio na solução em $434 \mathrm{mg} \mathrm{L}^{-1}$.

A produção de matéria seca das raizes variou significativamente $(P<0,01)$ com as doses de nitrogênio. Através da equação de regressão apresentada na Figura 3, têm-se que a máxima produção das raízes ocorreria além da dose limite de nitrogênio estudada, com o emprego de nutriente em $484 \mathrm{mg} \mathrm{L}^{-1}$.

Santos (1997) verificou máxima produção de matéria seca das raizes de capim-braquiária com a dose de nitrogênio de $453 \mathrm{mg} \mathrm{L}^{-1}$ na solução. Esse autor destacou a importância do nitrogênio no aumento no volume radicular, como uma das causas da maior produção de matéria seca da parte aérea da gramínea no segundo periodo de crescimento. 


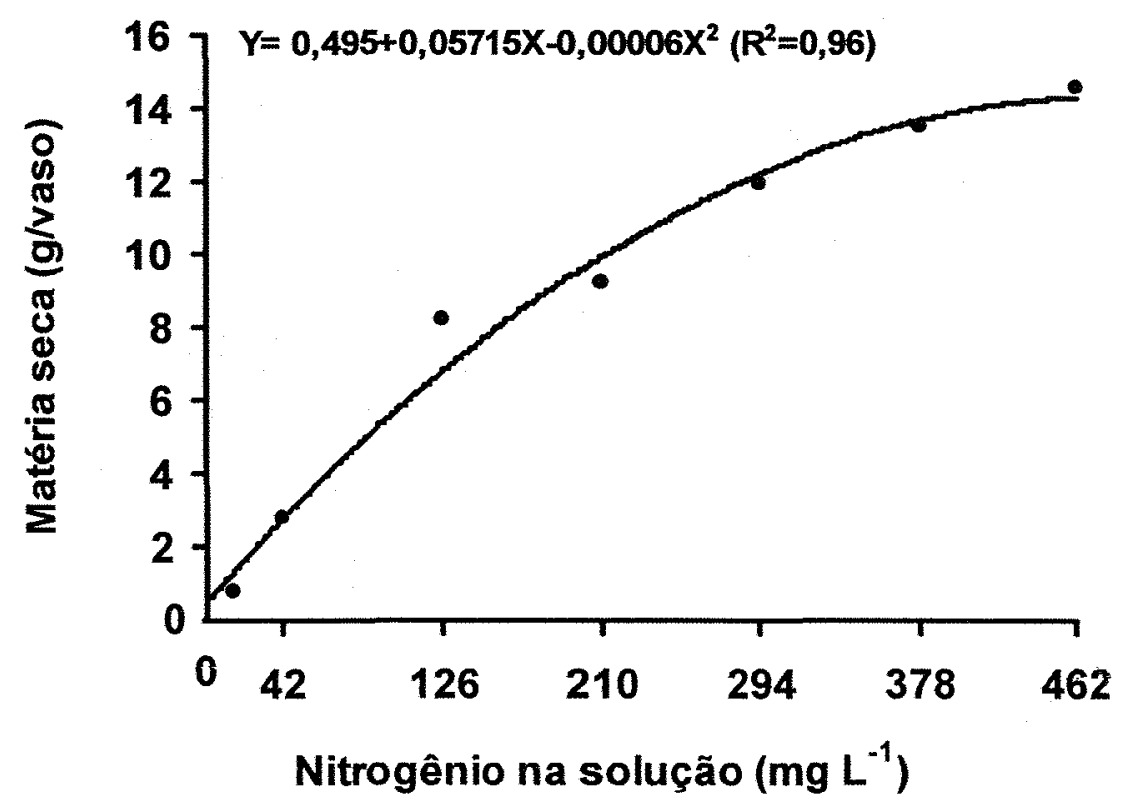

Figura 3. Produção de matéria seca das raízes do capim-Mombaça, em função das doses de nitrogênio.

De acordo com a equação apresentada o valor máximo de matéria seca das raízes seria encontrado com a dose de nitrogênio de $484 \mathrm{mg} \mathrm{L}^{-1}$, dose essa superior ao limite estudado neste experimento. Corrêa (1996), estudando os cultivares Colonião, Tanzânia-1 e Vencedor de Panicum maximum, três doses de nitrogênio $\left(42,210\right.$ e $\left.378 \mathrm{mg} \mathrm{L}^{-1}\right)$ e duas doses de magnésio $\left(4,8\right.$ e $48 \mathrm{mg} \mathrm{L}^{-}$ $\left.{ }^{1}\right)$ em solução nutritiva, não encontrou diferença significativa entre as doses de nitrogênio quanto à produção de matéria seca das raízes em qualquer das doses de magnésio utilizadas.

\subsection{Número de perfilhos}

O número de perfilhos, em ambos os cortes, foi significativamente $(P<0,05)$ influenciado pela concentração de nitrogênio na solução nutritiva. No primeiro crescimento foi constatado que o número de perfilhos aumentou significativamente até a dose de $126 \mathrm{mg} \mathrm{L}^{-1}$. Esta dose não diferiu 
estatisticamente da mais elevada dose estudada (462 $\mathrm{mg} \mathrm{L}^{-1}$ ). As doses mais altas de nitrogênio de 294, 378 e $462 \mathrm{mg} \mathrm{L}^{-1}$ não diferiram entre si porém, a dose de nitrogênio de $378 \mathrm{mg} \mathrm{L}^{-1}$ apresentou número de perfilho superior ao encontrado nas doses igual ou inferiores a $210 \mathrm{mg} \mathrm{L}^{-1}$ (Figura 4). Para a braquiária decumbens Santos (1997) relatou que o número de perfilhos aumentou significativamente com o nitrogênio até a dose $378 \mathrm{mg}$ de N L ${ }^{-1}$ de solução.

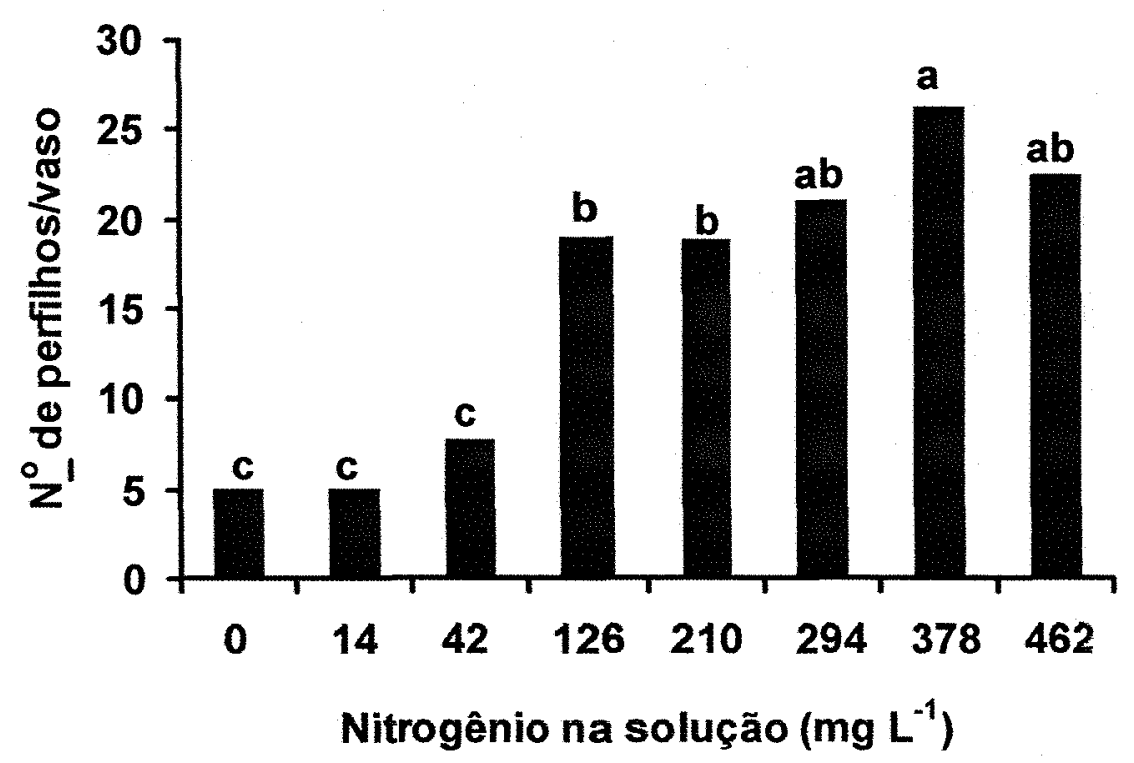

Figura 4. Número de perfilhos nas cinco plantas do Panicum maximum cultivar Mombaça no primeiro corte, em função das doses de nitrogênio.

A Figura 5 mostra a gramínea três dias após o primeiro corte, evidenciando a redução no crescimento da planta submetidas às mais baixas doses de nitrogênio. Em condições da dose 0 de nitrogênio, conforme encontrado por Santos (1997), os efeitos foram drásticos no segundo crescimento da forrageira, inclusive não havendo rebrota para produção de matéria seca da parte aérea a partir do primeiro crescimento. 


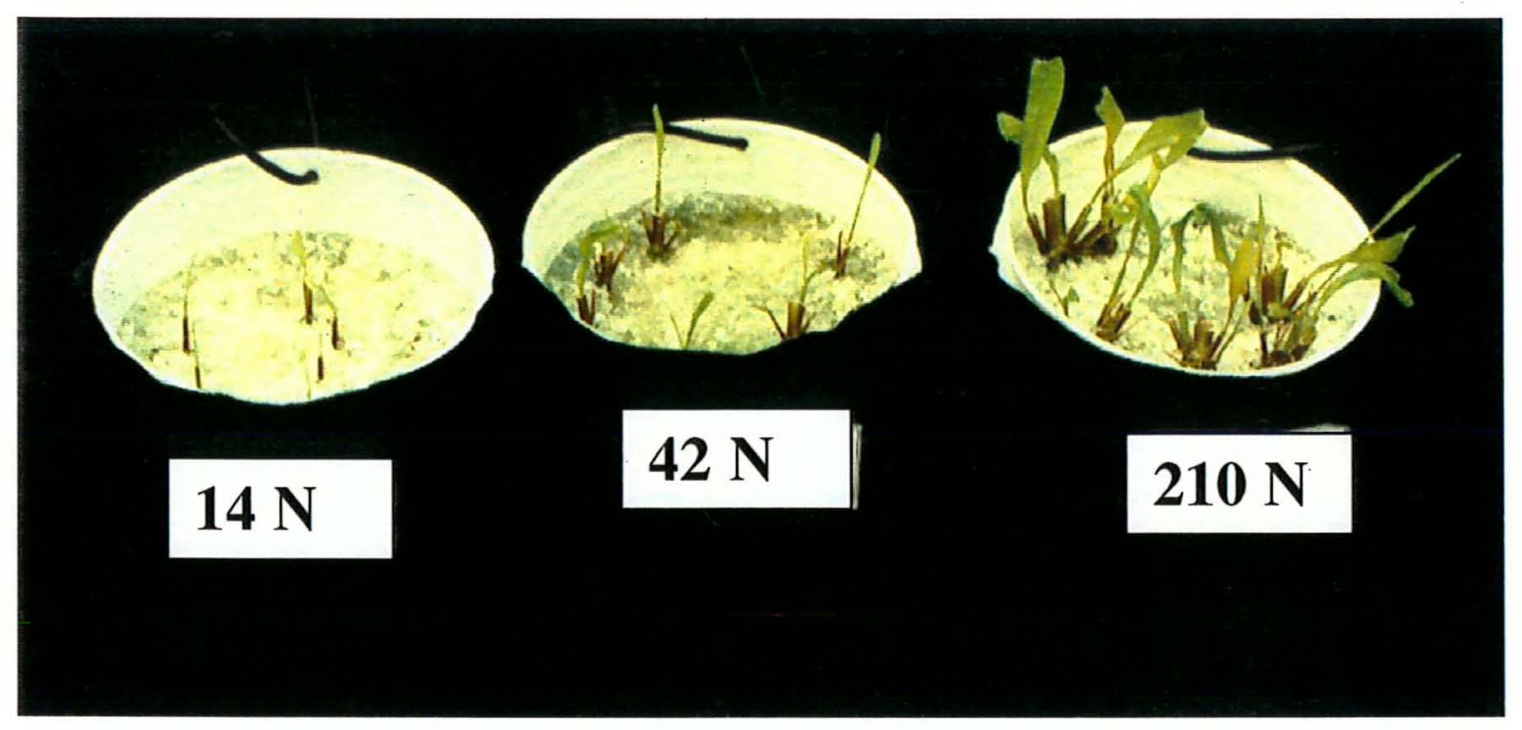

Figura 5. Rebrota do Panicum maximum cultivar Mombaça, três dias após o primeiro corte.

No segundo período de crescimento, o número de perfilhos aumentou significativamente da dose de nitrogênio de 14 para as de 42 e $126 \mathrm{mg} \mathrm{L}^{-1}$. Porém, com relação à dose $126 \mathrm{mg}$ de $\mathrm{N} \mathrm{L}^{-1}$ o número de perfilhos foi menor do que o obtido nas doses de 378 e $462 \mathrm{mg}$ de $\mathrm{N} \mathrm{L}^{-1}$, as quais não variaram. Nas doses 126, 210 e $294 \mathrm{mg} \mathrm{L}^{-1}$, como no primeiro corte, não ocorreu diferença significativa no número de perfilhos, nesse período de crescimento (Figura 6).

O efeito positivo do nitrogênio no número de perfilhos foi destacado por Monteiro e Werner (1977), Abreu (1994), Corrêa (1996) para vários cultivares de Panicum maximum e para Colozza (1998) especificamente para o cultivar Mombaça. 


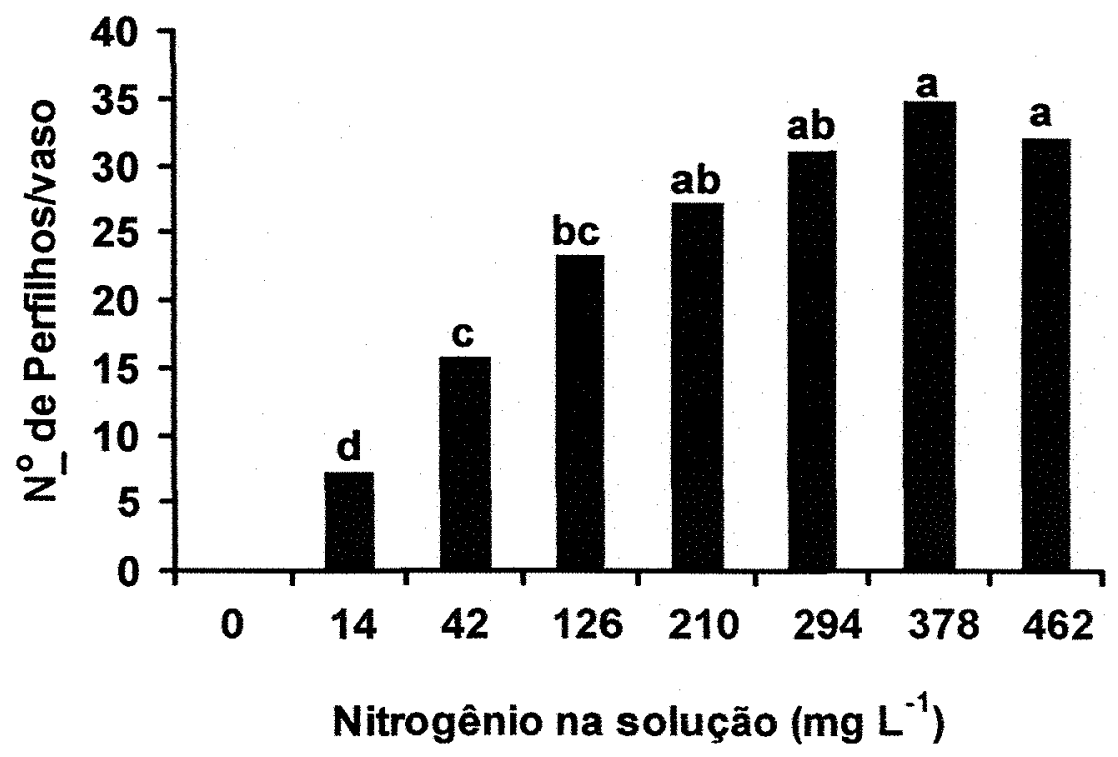

Figura 6. Número de perfilhos nas cinco plantas do Panicum maximum cultivar Mombaça no segundo corte, em função das doses de nitrogênio.

De acordo com o encontrado por Colozza (1998), no primeiro corte, o número médio de perfilhos foi menor que o verificado no segundo, podendo se atribuir ao fato da planta estar no primeiro crescimento em fase de estabelecimento e de formação do sistema radicular.

\section{3 Área foliar}

A área foliar das folhas não-expandidas no primeiro corte do capimMombaça no primeiro corte foi significativamente influenciada $(P<0,01)$ pelas doses de nitrogênio e representada por uma equação linear. $\mathrm{Na}$ dose mais elevada utilizada neste experimento foram encontrados $647,17 \mathrm{~cm}^{2} /$ vaso como área das folhas não-expandidas do capim-Mombaça (Figura 7). 


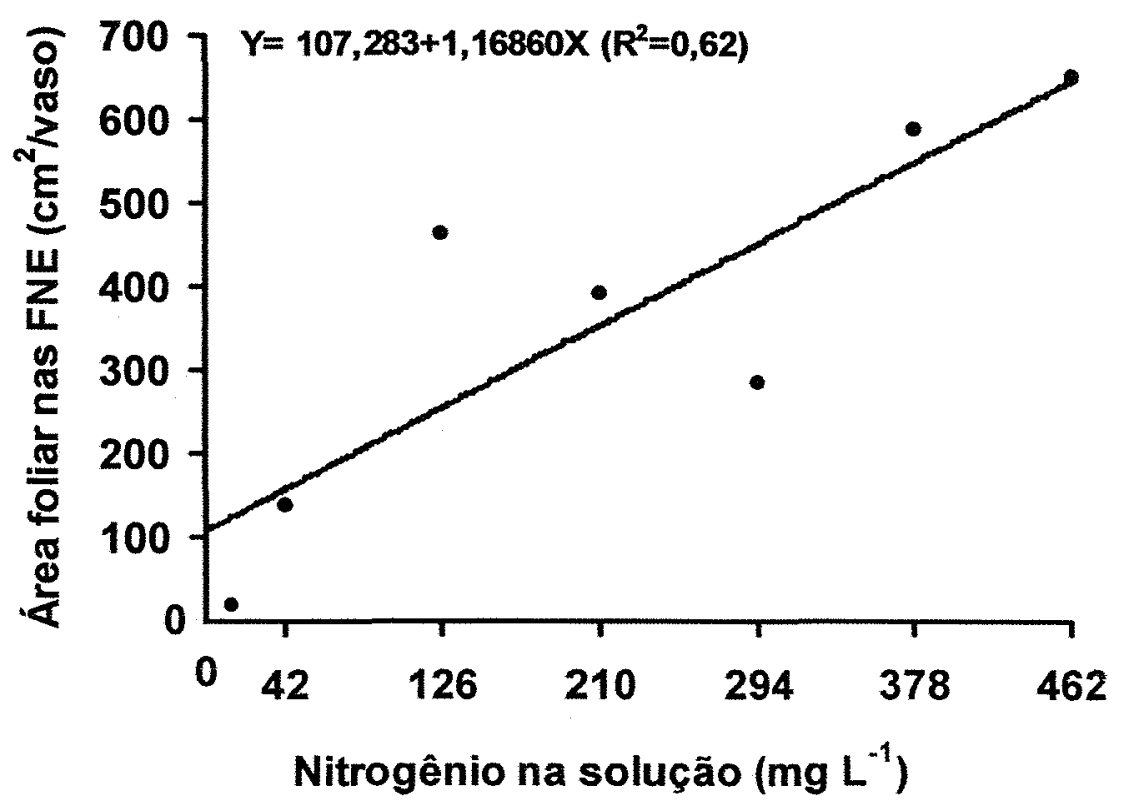

Figura 7. Área foliar das folhas não-expandidas (FNE) do capim-Mombaça no primeiro corte, em função das doses de nitrogênio na solução.

Nas figuras 8 e 9 estão apresentados os gráficos correspondentes a área foliar das lâminas de folhas novas e lâminas de folhas velhas do capimMombaça, respectivamente. Esses componentes variaram significativamente $(P<0,01)$ com as doses de nitrogênio e ajustaram-se a modelo quadrático.

A área foliar das lâminas de folhas novas atingiu o ponto máximo com a dose de nitrogênio de $412,9 \mathrm{mg} \mathrm{L}^{-1}$, semelhante ao que ocorreu com a lâmina de folhas velhas que atingiu o seu máximo com a dose de nitrogênio igual a $433,9 \mathrm{mg} \mathrm{L}^{-1}$. A parte da planta que apresentou maior área foliar, dentro dos limites estudados, foi a lâmina de folha nova. 


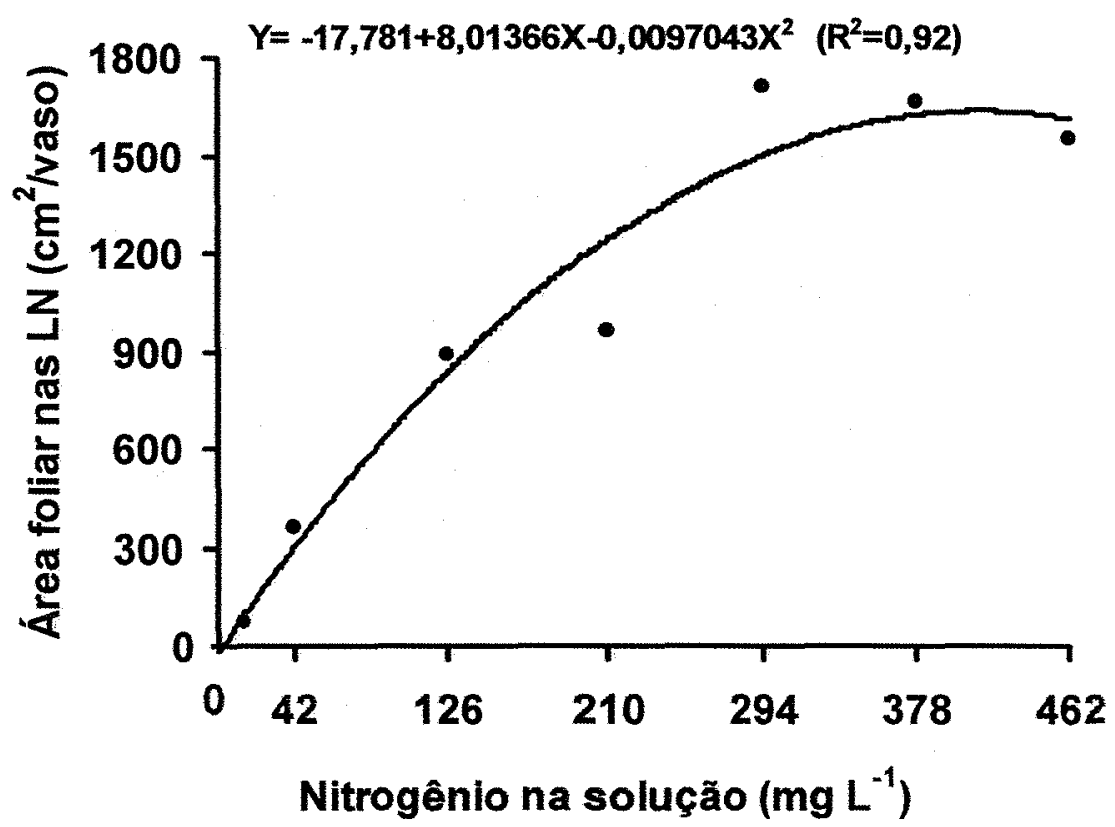

Figura 8. Área foliar das lâminas de folhas novas (LN) do capim-Mombaça no primeiro corte, em função das doses de nitrogênio na solução.

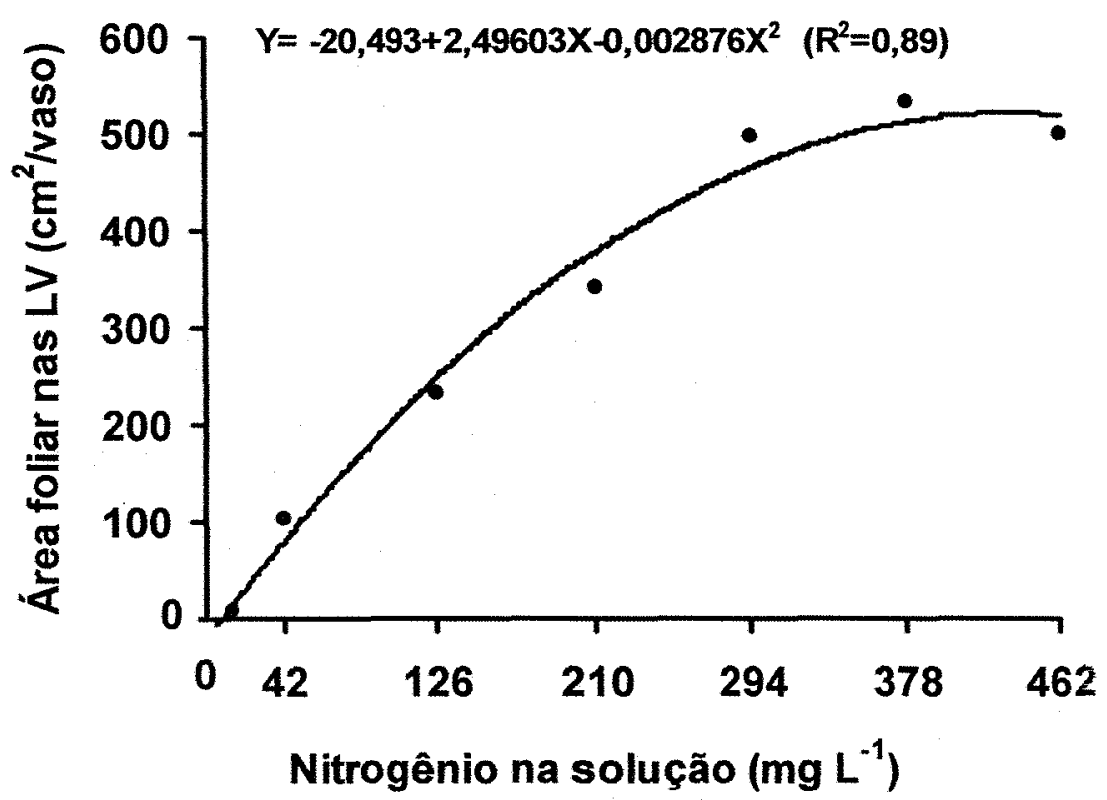

Figura 9. Área foliar das lâminas de folhas velhas (LV) do capim-Mombaça no primeiro corte, em função das doses de nitrogênio na solução. 
No segundo período de crescimento, a área foliar das lâminas de folhas não-expandidas variou significativamente $(P<0,01)$ com as doses de nitrogênio na solução e respondeu a essas doses segundo um modelo quadrático (Figura 10). O ponto de máxima área foliar ocorreu com a dose de nitrogênio de 338 $\mathrm{mg} \mathrm{L}^{-1}$ na solução.

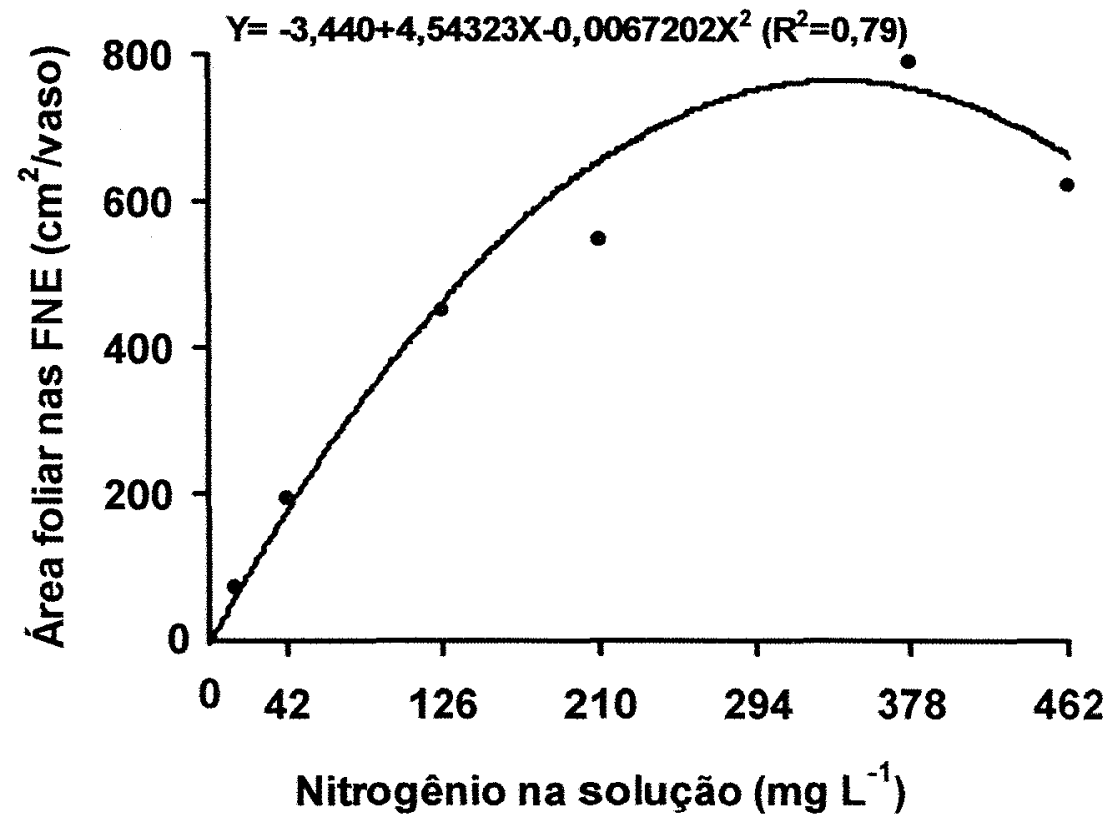

Figura 10. Área foliar das folhas não-expandidas (FNE) do capim-Mombaça no segundo corte, em função das doses de nitrogênio na solução.

A área foliar do componente lâmina de folha nova variou de acordo com uma equação de segundo grau e foi significativamente $(P<0,01)$ alterada em função do incremento nas doses de nitrogênio (Figura 11). O ponto de máxima área foliar ocorreu além do limite de nitrogênio utilizado nesse estudo e se daria na dose de $485 \mathrm{mg} \mathrm{L}^{-1}$.

A área foliar da lâmina de folha velha apresentou ajuste a modelo quadrático de regressão para a época do segundo corte. $O$ ponto de máxima área foliar ocorreu, nessa parte da planta, com a dose de nitrogênio de 347,7 $\mathrm{mg} \mathrm{L}^{-1}$ (Figura 12). No segundo corte, a parte da planta que apresentou maior 
área foliar foi a lâmina de folha nova seguida da lâmina de folha velha e da Ifolha não-expandida.

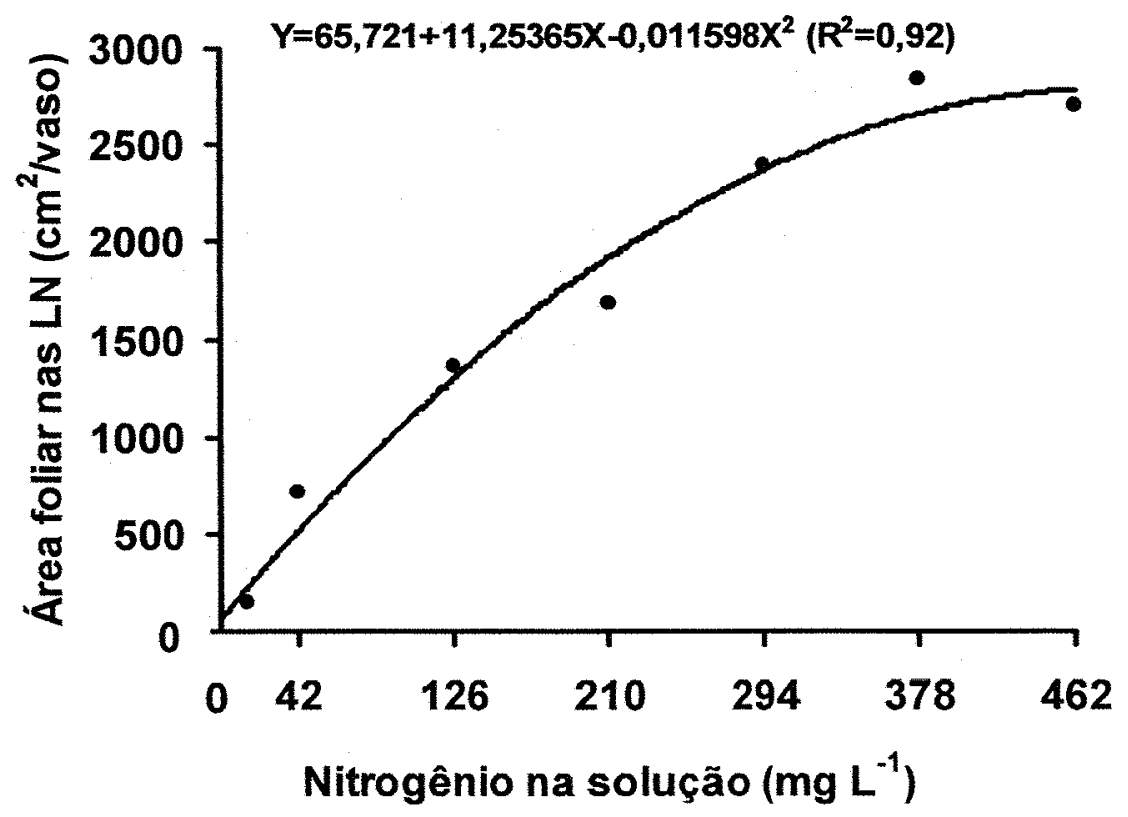

Figura 11. Área foliar das folhas novas (LN) do capim-Mombaça no segundo corte, em função das doses de nitrogênio na solução.

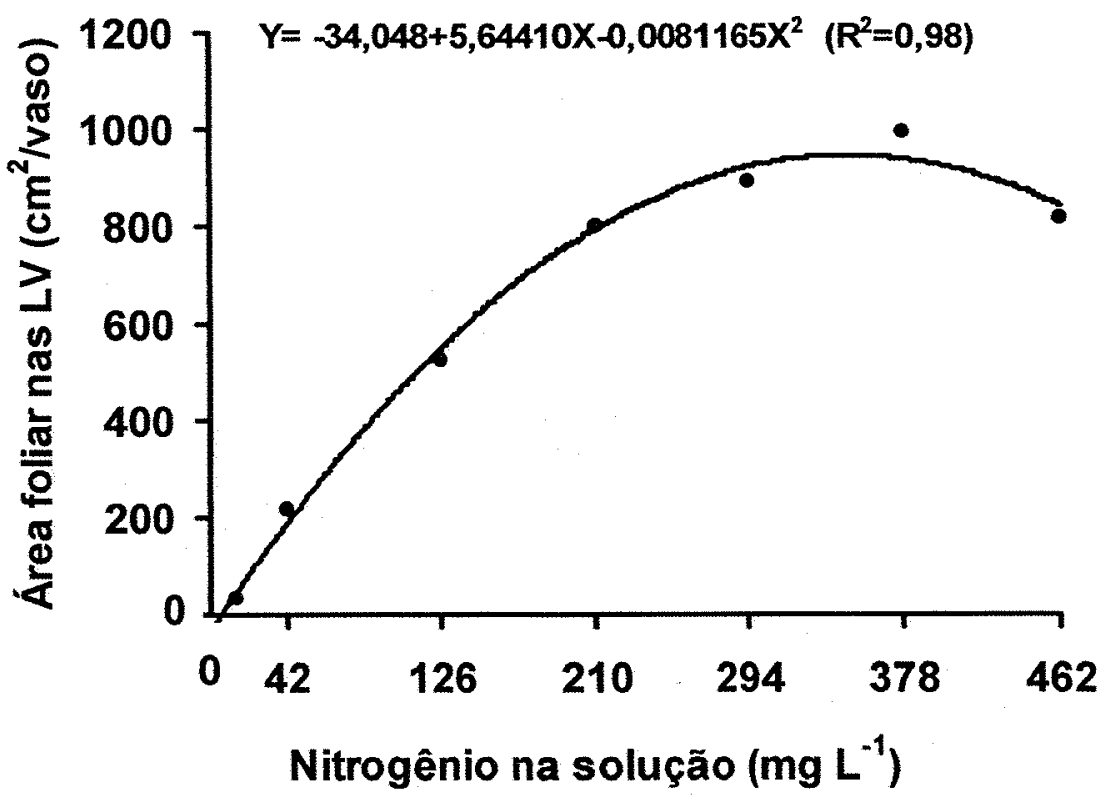

Figura 12. Área foliar das folhas velhas (LV) do capim-Mombaça no segundo corte, em função das doses de nitrogênio na solução. 


\subsection{Atividade da redutase do nitrato}

$A$ atividade da redutase do nitrato variou significativamente $(P<0,05)$ e $(P<0,01)$ em relação às doses de nitrogênio na solução, no primeiro e segundo períodos de crescimento, respectivamente.

Nos dois períodos de crescimento a atividade da redutase do nitrato no capim-Mombaça, em função do suprimento de nitrogênio, se ajustou a modelo quadrático. Porém, no primeiro corte houve um baixo coeficiente de correlação, enquanto no segundo corte esse coeficiente foi igual a 0,94 (Figuras 13 e 14).

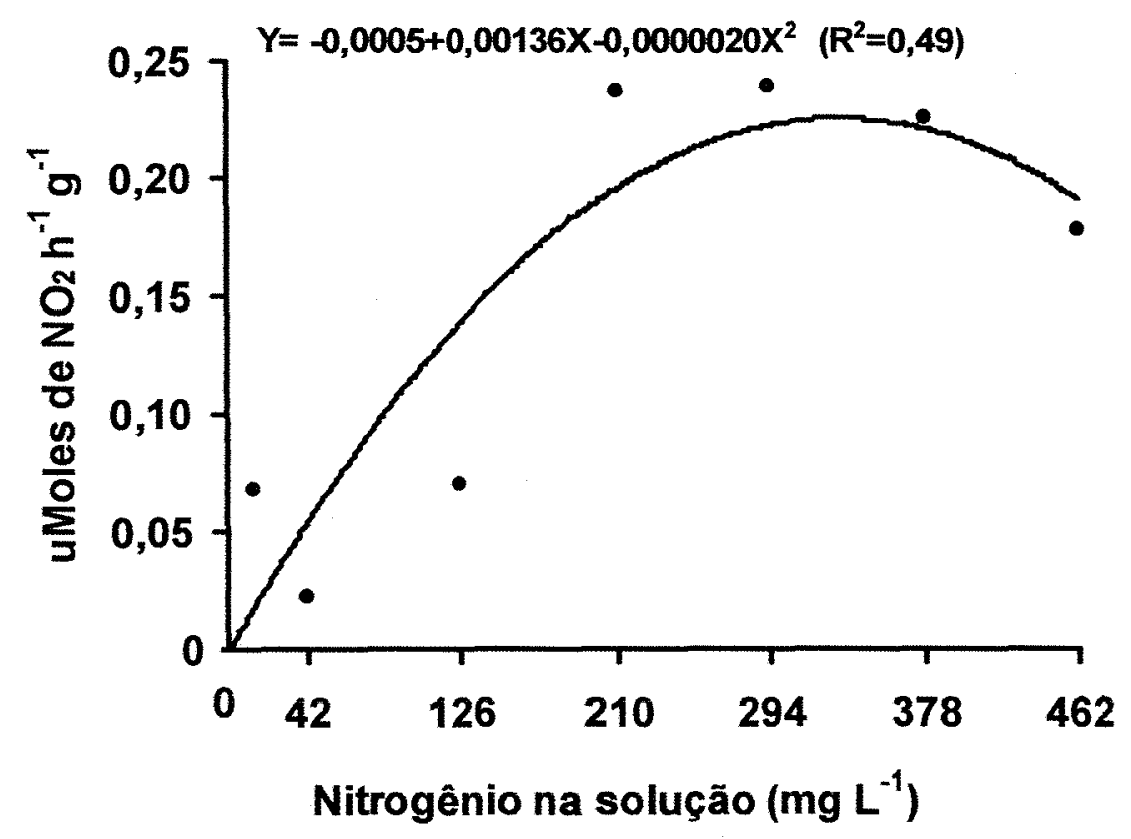

Figura 13. Atividade da enzima redutase do nitrato no primeiro crescimento do capim-Mombaça, em função das doses de nitrogênio na solução.

Houve um aumento na atividade desta enzima em função do incremento nas doses de nitrogênio, até atingir o ponto máximo com nitrogênio na solução em $340 \mathrm{mg} \mathrm{L}^{-1}$. A partir desse ponto a atividade dessa enzima mostrou decréscimo com o suprimento do nutriente no substrato (Figura 13). Corrêa 
(1996), encontrou aumento linear na atividade dessa enzima em função de doses de nitrogênio mais elevadas que $210 \mathrm{mg} \mathrm{L}^{-1}$.

Utilizando como referência a dose de nitrogênio de $210 \mathrm{mg} \mathrm{L}^{-1}$ de solução, na equação de regressão apresentada na Figura 13 , verificou-se que no primeiro crescimento da planta a máxima atividade da redutase do nitrato foi de $0,20 \mu$ moles de $\mathrm{NO}^{2} \mathrm{~h}^{-1} \mathrm{~g}^{-1}$ de material vegetal fresco. Esse valor foi encontrado também por Santos (1997) para o capim-braquiária. Porém, com o uso da mesma referência no segundo crescimento, o valor encontrado para a atividade da redutase do nitrato representada na equação da Figura 14 foi de $0,09 \mathrm{NO}^{2} \mathrm{~h}^{-1} \mathrm{~g}^{-1}$. Esse valor está muito abaixo do encontrado por Santos (1997) de $0,19 \mathrm{NO}^{2} \mathrm{~h}^{-1} \mathrm{~g}^{-1}$ para o capim-braquiária.

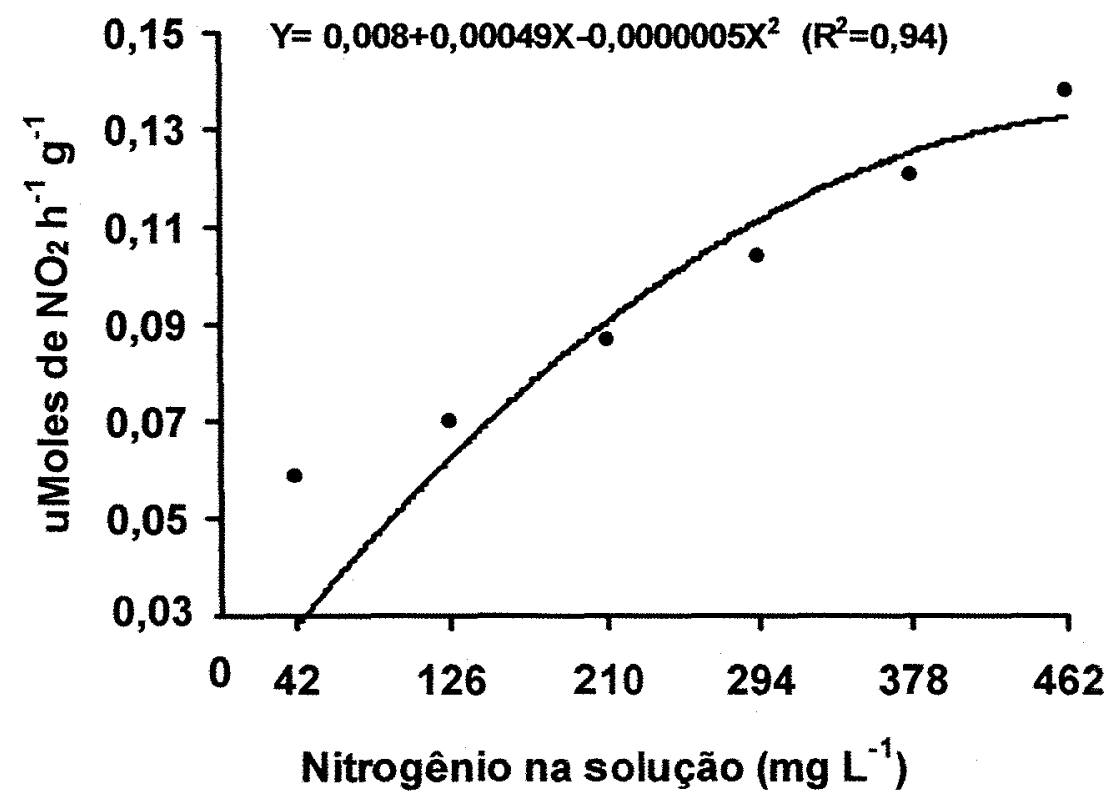

Figura 14. Atividade da enzima redutase do nitrato no segundo crescimento do capim-Mombaça, em função das doses de nitrogênio na solução.

No segundo crescimento da forrageira o ponto de máxima atividade da enzima redutase do nitrato ocorreria além do limite de nitrogênio utilizado nesse estudo, com o nitrogênio na solução em de $491 \mathrm{mg} \mathrm{L}^{-1}$. O nitrogênio teve efeito 
positivo na atividade dessa enzima, dentro dos limites apontados, tanto no primeiro como no segundo período de crescimento.

\subsection{Estimativa do teor de clorofila através do valor SPAD}

Os valores SPAD resultantes das estimativas do teor de clorofila na lâmina foliar do capim-Mombaça, em função das doses de nitrogênio, são apresentados nas Figuras 15 e 16, respectivamente para os períodos do primeiro e do segundo crescimentos da forrageira. Esses valores variaram significativamente $(P<0,01)$ com o fornecimento de nitrogênio na solução nutritiva.

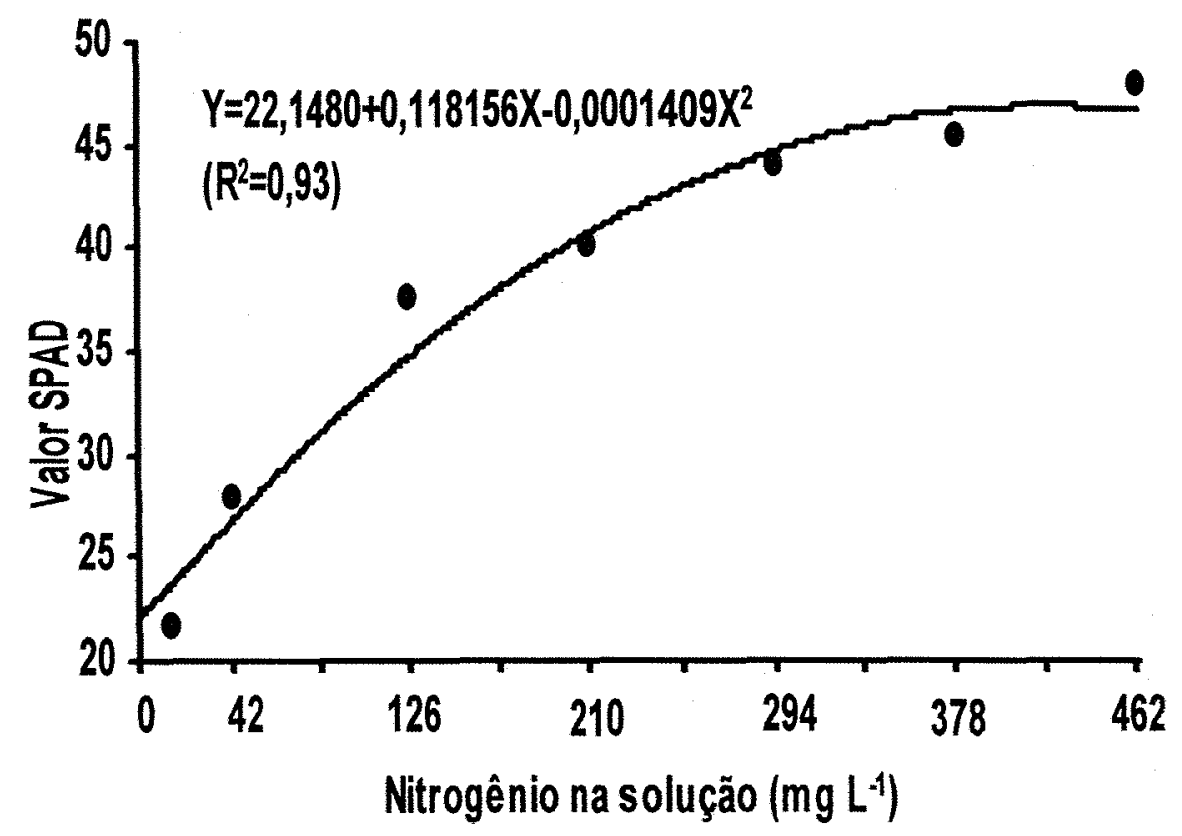

Figura 15. Teor de clorofila determinado em unidade de valor SPAD no primeiro crescimento do capim-Mombaça, em função das doses de nitrogênio na solução.

No primeiro crescimento do capim os valores SPAD apresentaram ajuste ao modelo quadrático de regressão. $A$ análise da equação de segundo grau 
mostra que o valor SPAD variou entre 22,1 e 46,9 entre a condição de omissão de nitrogênio na solução e a dose de nutriente que proporcionou máximo valor SPAD (o qual ocorreu com nitrogênio em $419,3 \mathrm{mg}_{\text {de }} \mathrm{L}^{-1}$ ).

No segundo crescimento, os resultados das leituras SPAD foram significativamente $(P<0,01)$ alterados em função das doses de nitrogênio e apresentaram ajuste a modelo linear (Figura 16).

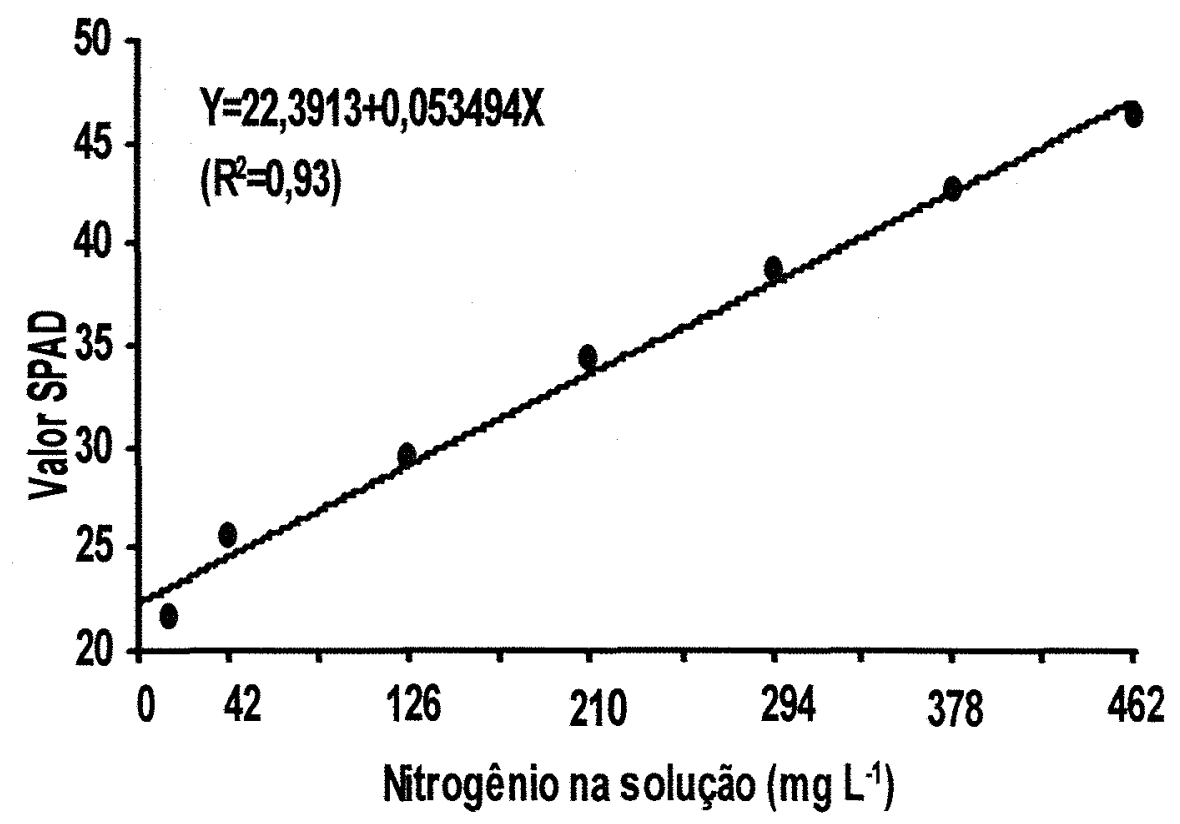

Figura 16. Teor de clorofila determinado em unidades de valor SPAD no segundo crescimentodo capim-Mombaça, em função das doses de nitrogênio na solução.

O alto coeficiente de correlação encontrado entre as leituras do clorofilômetro e as doses de nitrogênio (Figuras 15 e 16) confirmam os resultados encontados por Santos (1997) e comprovam a possibilidade de utilização desse aparelho para predizer o estado nutricional dessa forrageira quanto ao nitrogênio. 


\subsection{Concentração de nitrogênio na planta}

\subsubsection{Folhas não-expandidas}

A concentração de nitrogênio nas folhas não-expandidas da forrageira mostrou variação significativa $(P<0,01)$ no material colhido no primeiro e no segundo corte, com as doses de nitrogênio.

Tanto no primeiro como no segundo corte a concentração de nitrogênio nesse tecido vegetal variou segundo modelo linear com as doses do nutriente utilizadas na solução (Figuras 17 e 18).

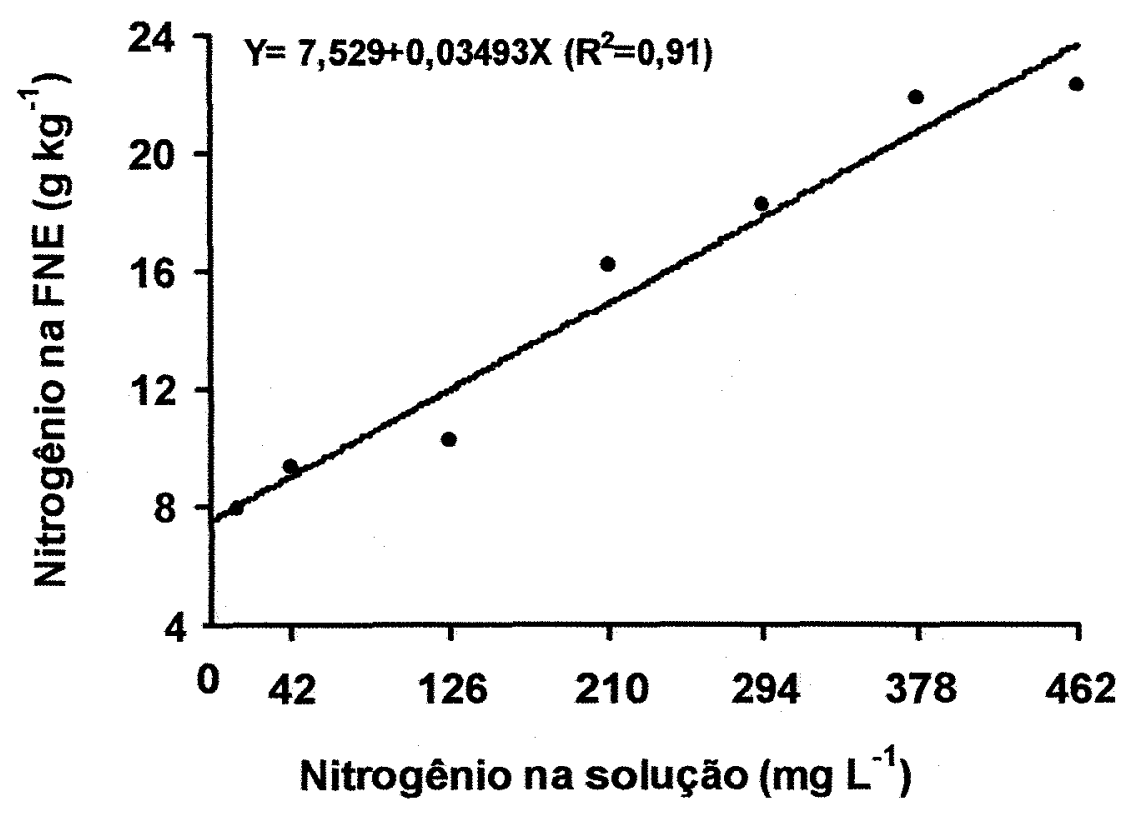

Figura 17. Concentração de nitrogênio nas folhas não-expandidas (FNE) no primeiro corte do capim-Mombaça, em função das doses de nitrogênio na solução.

A variação na concentração de nitrogênio nas folhas não-expandidas foi de 7,5 a 23,7 , e 11,4 a $24,5 \mathrm{~g} \mathrm{~kg}^{-1}$ de matéria seca, nos limites das doses 
estudadas para o primeiro e segundo cortes da forrageira, respectivamente. Essa parte da planta, tanto no primeiro como no segundo crescimento, foi a que apresentou mais elevada concentração de nitrogênio quando o capim foi submetido à mais elevada dose na solução. Santos(1997) obteve resultados semelhantes, deixando claro que nesse componente da planta há possibilidade de aumentar a concentração de nitrogênio se aplicadas doses superiores às utilizadas no presente experimento. Isto é reflexo da movimentação do nitrogênio para partes novas da planta e tem conseqüência para $\circ$ animal que normalmente prefere partes novas no pastejo.

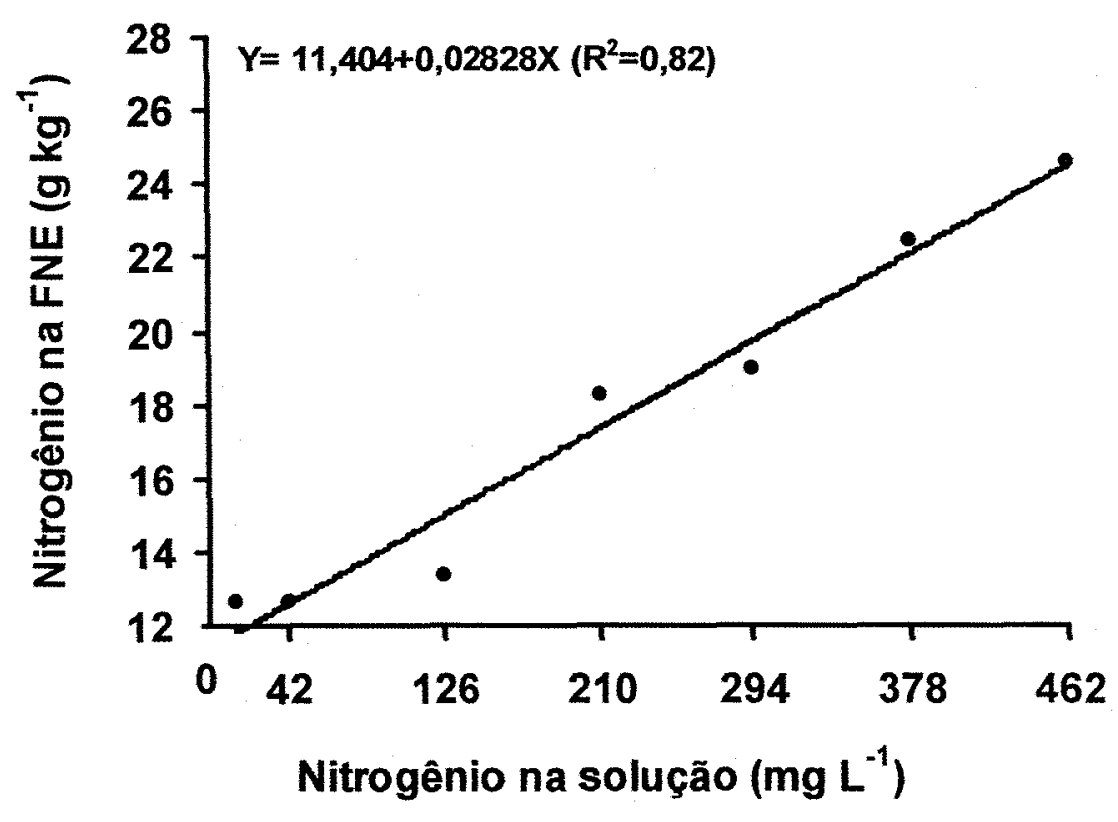

Figura 18. Concentração de nitrogênio nas folhas não-expandidas (FNE) no segundo corte do capim-Mombaça, em função das doses de nitrogênio na solução.

\subsubsection{Lâminas de folhas novas}

A concentração de nitrogênio total nas lâminas de folhas novas foi linear e significativamente $(P<0,01)$ incrementada pelas doses de nitrogênio, tanto no 
material colhido no primeiro (Figura 19) como no segundo corte (Figura 20) do capim-Mombaça.

A variação da concentração de nitrogênio nas lâminas de folhas novas foi de 8,8 a 18,5, e 10,2 a $19,2 \mathrm{~g} \mathrm{~kg}^{-1}$ de matéria seca, nos limites das doses estudadas, para a época do primeiro e do segundo corte da forrageira, respectivamente.

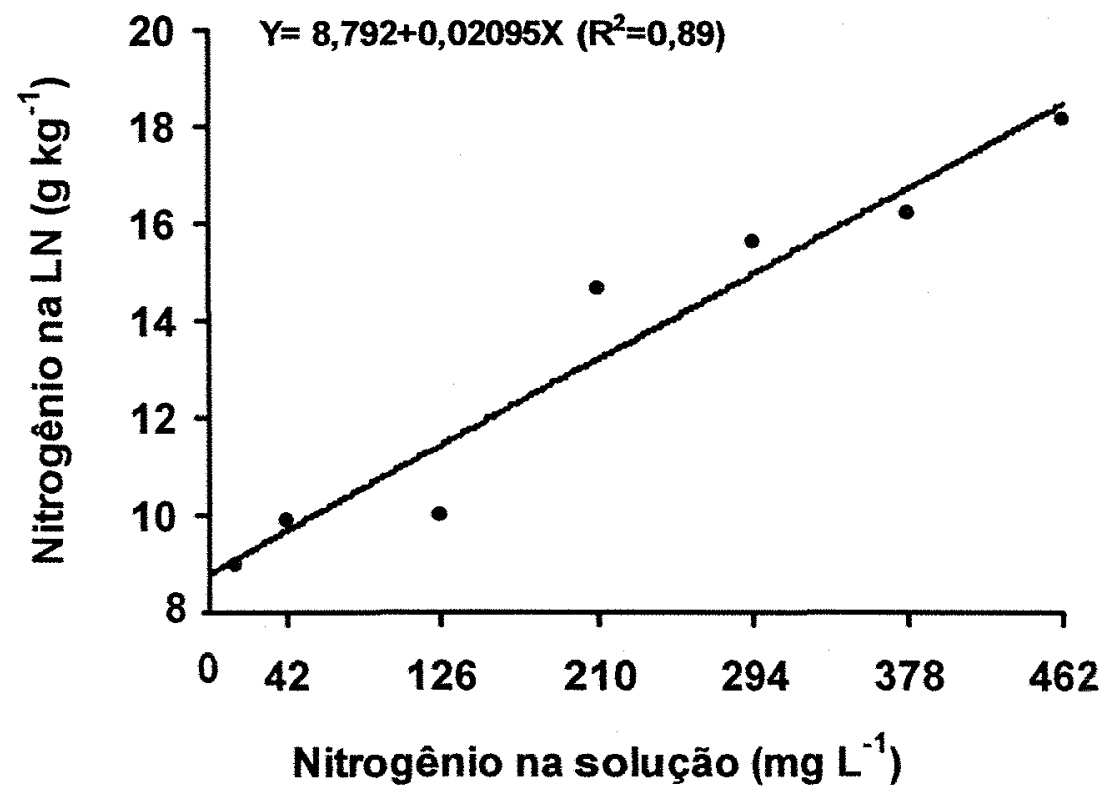

Figura 19. Concentração de nitrogênio nas lâminas de folhas novas (LN) no primeiro corte do capim-Mombaça, em função das doses de nitrogênio na solução.

Colozza(1998), trabalhando com o capim-Mombaça verificou no primeiro corte variação de pequena amplitude nas concentraçōes de nitrogênio total entre as lâminas de folhas não-expandidas, lâminas de folhas novas e lâminas de folhas velhas. 


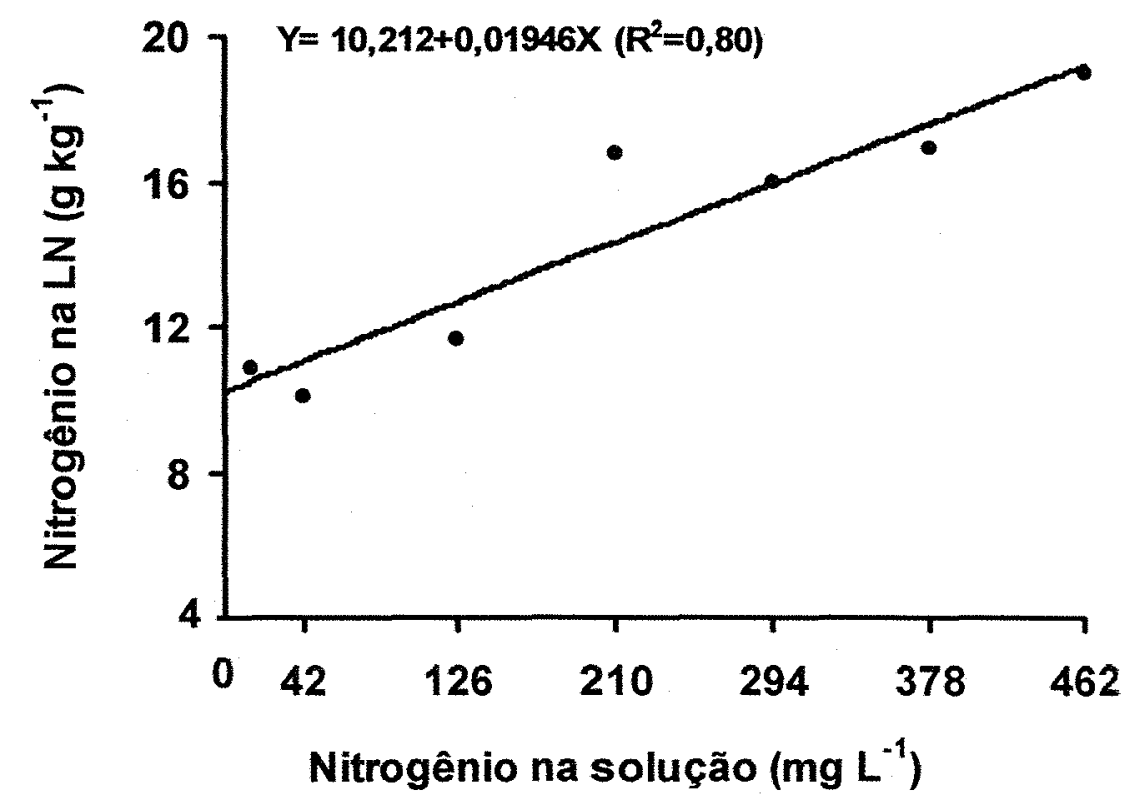

Figura 20. Concentração de nitrogênio nas lâminas de folhas novas (LN) no segundo corte do capim-Mombaça, em função das doses de nitrogênio na solução.

Santos (1997) também encontrou relação linear entre a concentração de nitrogênio nas lâminas de folhas novas e a dose de nitrogênio no substrato, para o primeiro corte. A variação nessa concentração, entre a omissão de nitrogênio e a maior dose utilizada, foi de 12,6 a $27,5 \mathrm{~g} \mathrm{~kg}^{-1}$ de matéria seca. No entanto, para o segundo crescimento encontrou ajuste a um modelo quadrático, estando a máxima concentração de nitrogênio em $19,0 \mathrm{~g} \mathrm{~kg}^{-1}$ de matéria seca, obtida na dose de nitrogênio de $391 \mathrm{mg} \mathrm{L}^{-1}$ de solução.

\subsubsection{Lâminas de folhas velhas}

A concentração de nitrogênio nas lâminas de folhas velhas variou significativamente $(P<0,01)$ apenas para o primeiro corte, com as doses de nitrogênio na solução nutritiva. Esse componente da parte aérea apresentou 
comportamento linear de resposta para as doses de nitrogênio no primeiro crescimento (Figura 21).

Nos limites das doses estudadas, no primeiro período de crescimento as lâminas de folhas velhas apresentaram uma variação de concentração de nitrogênio de 7,0 a $13,0 \mathrm{~g} \mathrm{~kg}^{-1}$ para condição da dose 0 e a de nitrogênio de 462 $\mathrm{mg} \mathrm{L}^{-1}$, respectivamente. A concentração de nitrogênio nas lâminas de folhas velhas, no primeiro corte, foi praticamente de mesmo valor que a encontrada nos colmos mais bainhas.

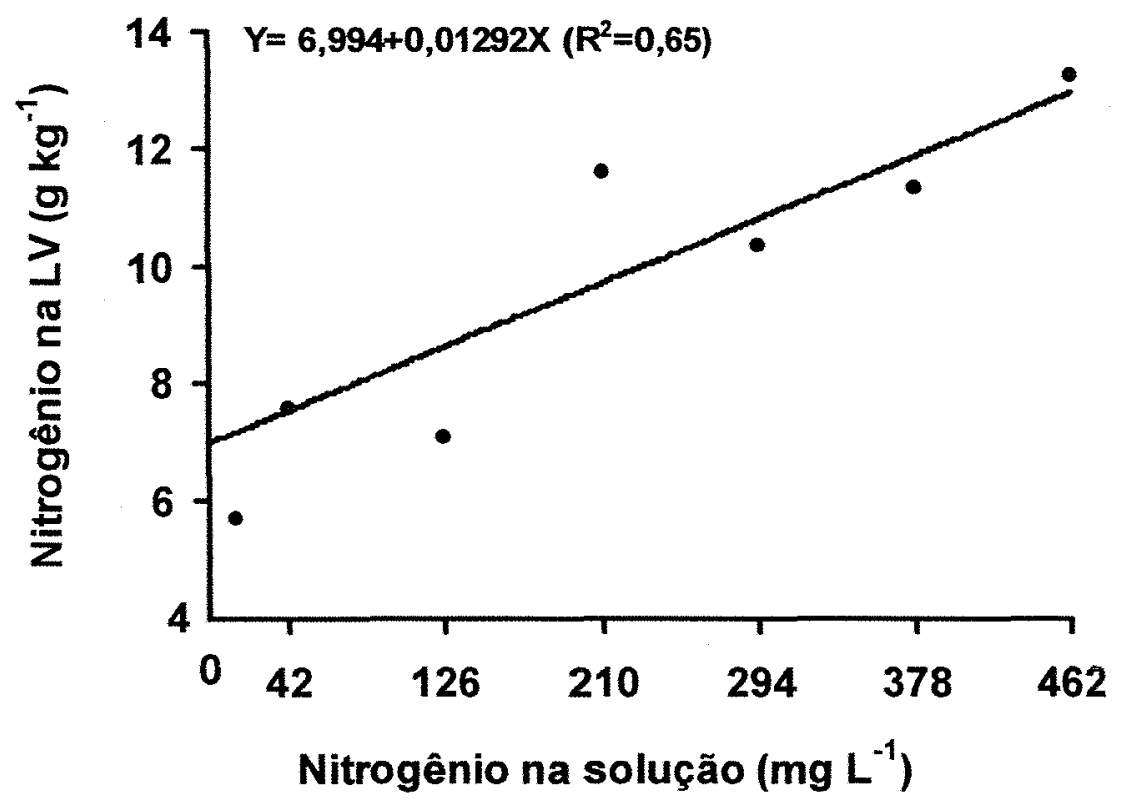

Figura 21. Concentração de nitrogênio nas lâminas de folhas velhas (LV) no primeiro corte do capim-Mombaça, em função das doses de nitrogênio na solução.

\subsubsection{Colmos mais bainhas}

Foi verificado efeito significativo $(P<0,05)$ das doses de nitrogênio na concentração de nitrogênio nos colmos mais bainhas do capim-Mombaça, no segundo crescimento. Esse efeito mostrou ajuste a modelo linear com as doses 
de nitrogênio na solução nutritiva. No primeiro crescimento não ocorreu variação significativa $(P>0,05)$ na concentração de nitrogênio nos colmos mais bainhas dessa gramínea submetida às doses de nitrogênio na solução nutritiva.

O ponto de máxima concentração de nitrogênio nesse componente da parte aérea do capim, no segundo corte, ocorreria além do limite de nitrogênio utilizado neste estudo (Figura 22).

A concentração de nitrogênio nos colmos mais bainhas do Panicum maximum cultivar Mombaça variou entre 6,35 e 15,9 com as doses mínima e máxima, no presente experimento.

Santos (1997) encontrou valores superiores $\left(21,4 \mathrm{~g} \mathrm{~kg}^{-1}\right.$ de matéria seca) nesse componente da planta com a dose de nitrogênio de $433 \mathrm{mg} \mathrm{N} \mathrm{L}^{-1}$ de solução. Outros autores (Abreu, 1994; Corrêa, 1996; Colozza, 1998) mostraram que esse esse componente da parte aérea foi o que apresentou as mais baixas concentrações de nitrogênio, quando doses do nutriente foram fornecidas no substrato de crescimento das plantas.

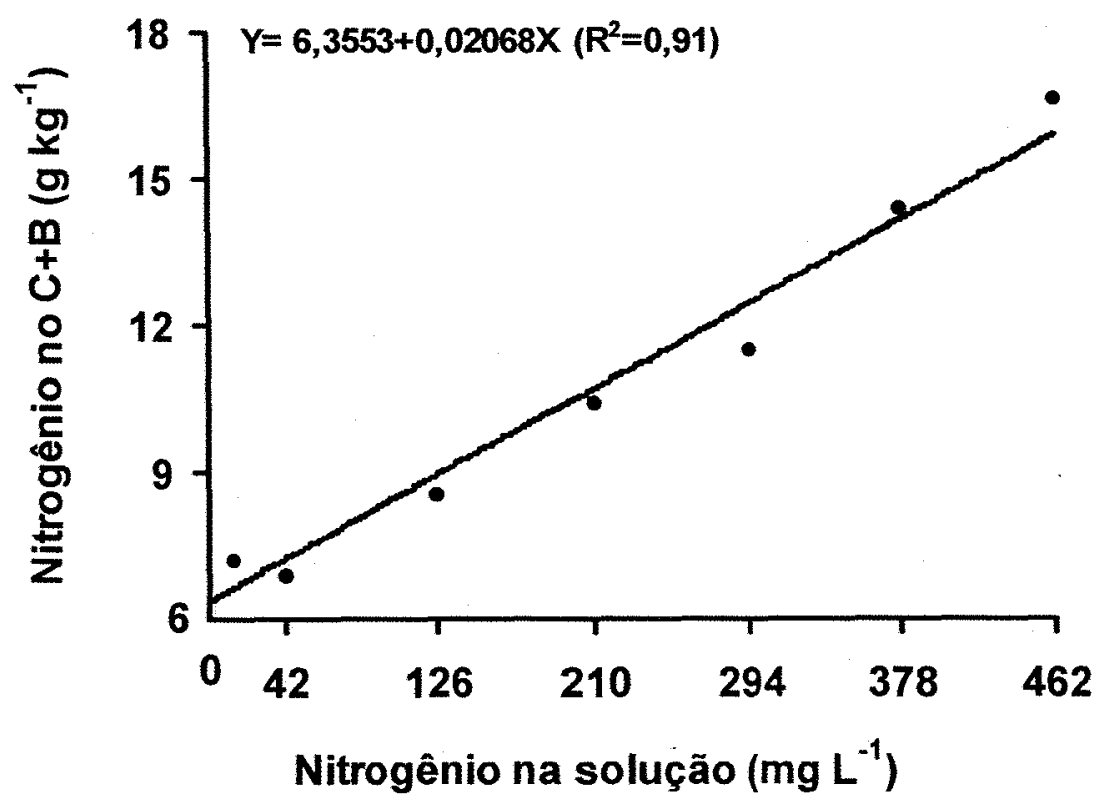

Figura 22. Concentração de nitrogênio nos colmos mais bainhas $(C+B)$ no segundo corte do capim-Mombaça, em função das doses de nitrogênio na solução. 


\subsubsection{Raízes}

A concentração de nitrogênio nas raízes do Panicum maximum cultivar Mombaça teve aumentos significativos $(P<0,01)$ com 0 incremento no fornecimento de nitrogênio na solução nutritiva. Nessa parte da planta, a concentração do nutriente variou conforme uma equação de primeiro grau em função das doses de nitrogênio utilizadas na solução nutritiva. A concentração do nitrogênio nas raízes do capim-Mombaça variou entre 8,2 e 18,6, em função das doses de nitrogênio (Figura 23). Colozza (1998) também encontrou variação linear na concentração de nitrogênio total nas raízes do capimmombaça com o fornecimento de nitrogênio.

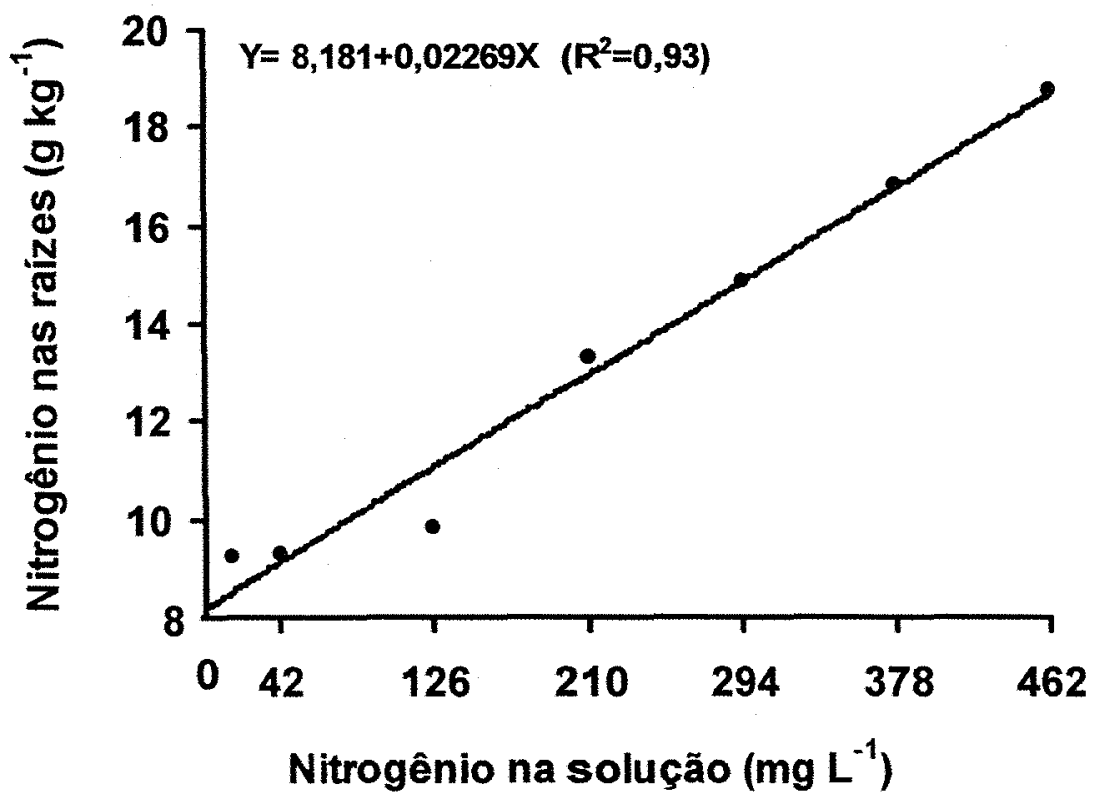

Figura 23. Concentração de nitrogênio nas raízes do capim-Mombaça, em função das doses de nitrogênio na solução. 


\subsection{Sintomas visuais}

Sintomas externos da deficiência de nitrogênio nas plantas puderam ser inicialmente notados com oito dias após o transplante das mesmas para os vasos experimentais.

No primeiro crescimento, nas mais baixas doses do nitrogênio, os sintomas de falta do nutriente foram bem definidos (Figura 24). Na ausência de nitrogênio as plântulas não se desenvolveram, emitindo apenas duas follhas que ficaram totalmente cloróticas e tiveram as bordas necrosadas. Esses sintomas puderam ser constatados até a dose de $126 \mathrm{mg} \mathrm{L}^{-1}$ de solução.

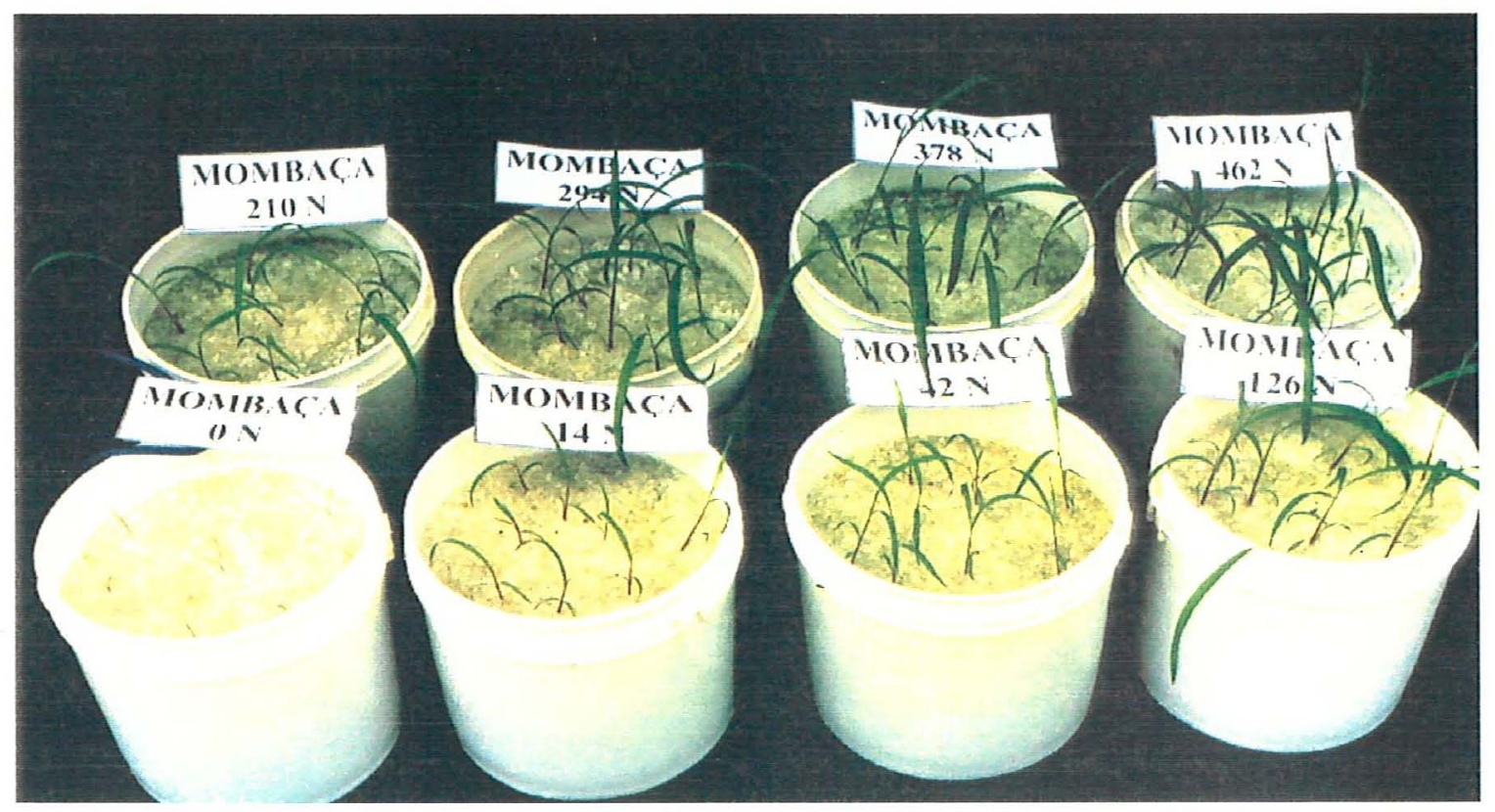

Figura 24. Sintomas de deficiência de nitrogênio nas plantas desenvolvidas nas doses mais baixas do nutriente na solução nutritiva. 
No segundo crescimento os sintomas foram mais intensos, afetando a rebrota das plantas submetidas às doses mais baixas de nitrogênio. Nessa condição a clorose intensa se deu nas folhas mais velhas, seguidas das folhas mais novas e das folhas não-expandidas. Houve também maior senescência das folhas até a dose de nitrogênio de $210 \mathrm{mg} \mathrm{L}^{-1}$ Observações semelhantes foram apresentadas por Santos et al. (1995) e Santos (1997).

Observando as raízes das plantas ao final do experimento, foi possível notar a grande influência do nitrogênio no desenvolvimento radicular (Figura 25), o que ocasionou maior absorção de nutrientes pelas plantas.

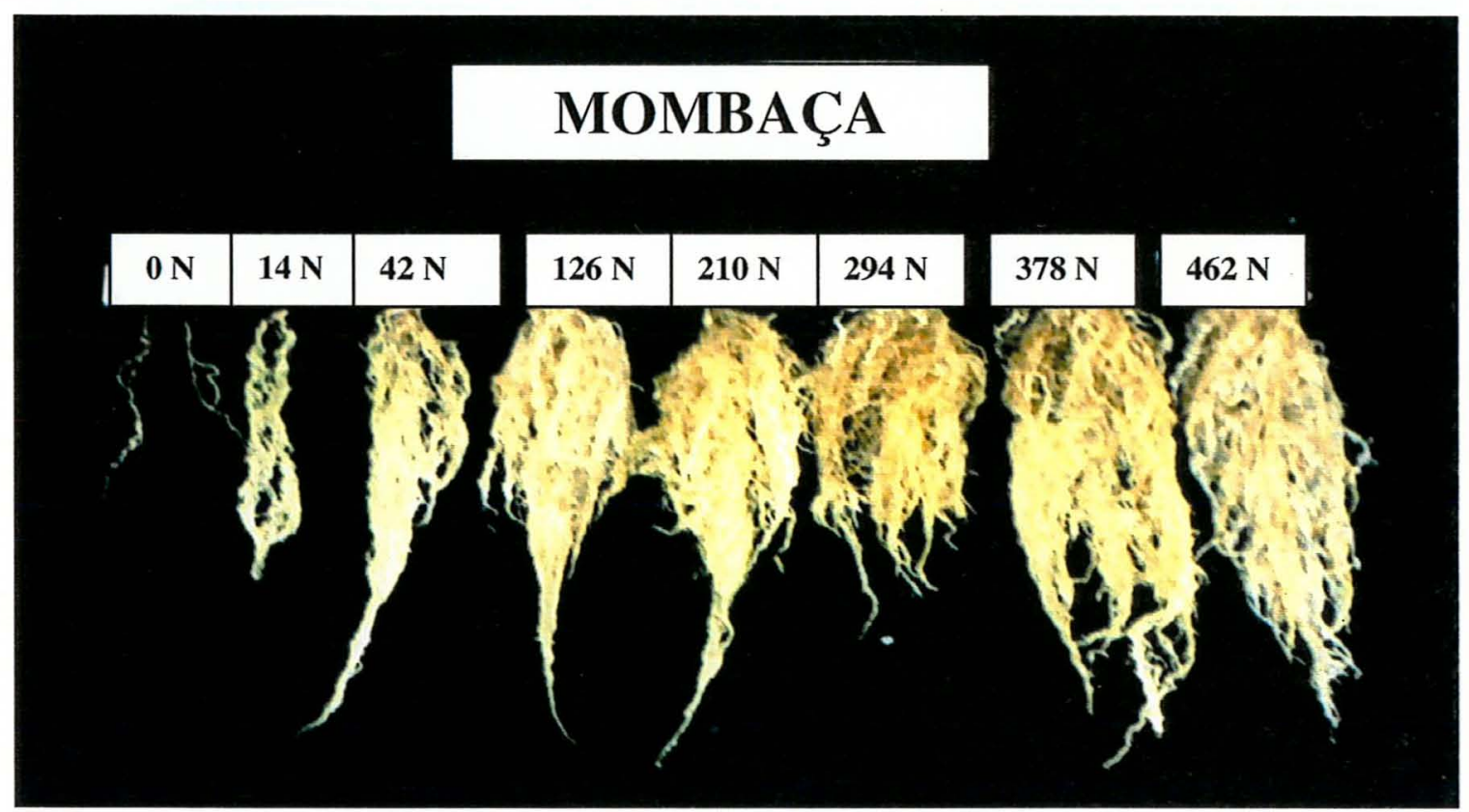

Figura 25. Raízes do capim-Mombaça coletadas após o segundo corte das plantas. 


\subsection{Nível crítico}

O estudo das correlações entre a concentração de nitrogênio em cada uma das quatro partes das plantas e a produção de matéria seca da parte aérea revelou que os mais elevados coeficientes entre essas variáveis foram obtidos para as concentrações de nitrogênio tanto nas folhas não-expandidas como nas de lâminas de folhas novas, no material coletado no primeiro e no segundo corte. Os coeficientes de correlação foram de 0,90 e 0,76 para as folhas não-expandidas e lâminas de folhas novas, respectivamente no primeiro corte e 0,82 em ambas as partes no segundo corte. Cabe destacar que a lâmina de folha nova é a que tem sido aconselhada para amostragem, pela facilidade operacional e é a que está sendo definida como a indicada para amostragem em outras situações experimentais, mesmo com outras gramíneas forrageiras e outros nutrientes (Santos et al., 1995; Santos, 1997; Colozza, 1998; Abreu, 1999).

A relação entre a concentração de nitrogênio nas lâminas de folhas novas da parte aérea e a produção de matéria seca foi significativa no primeiro corte $(P<0,05)$ e no segundo corte $(P<0,01)$. Essa relação foi representada por uma equação de primeiro grau no primeiro corte e por uma de segundo grau no segundo corte.

O conceito estabelecido por Ulrich \& Hill (1973) define o nivel crítico como a concentração do nutriente que corresponde a $90 \%$ da produção máxima da cultura e foi utilizado no presente experimento.

No primeiro corte, não foi encontrado um ponto de máximo correspondente às doses de nitrogênio (Figura 26). Porém, utilizando-se o ponto correspondente a $90 \%$ da máxima produção de matéria seca total do primeiro corte e relacionando-o com a concentração de nitrogênio no material desse mesmo corte nas lâminas de folhas novas foi possivel obter o nivel critico para esse crescimento, o qual correspondeu $a 16,5 \mathrm{~g} \mathrm{~kg}^{-1}$. 


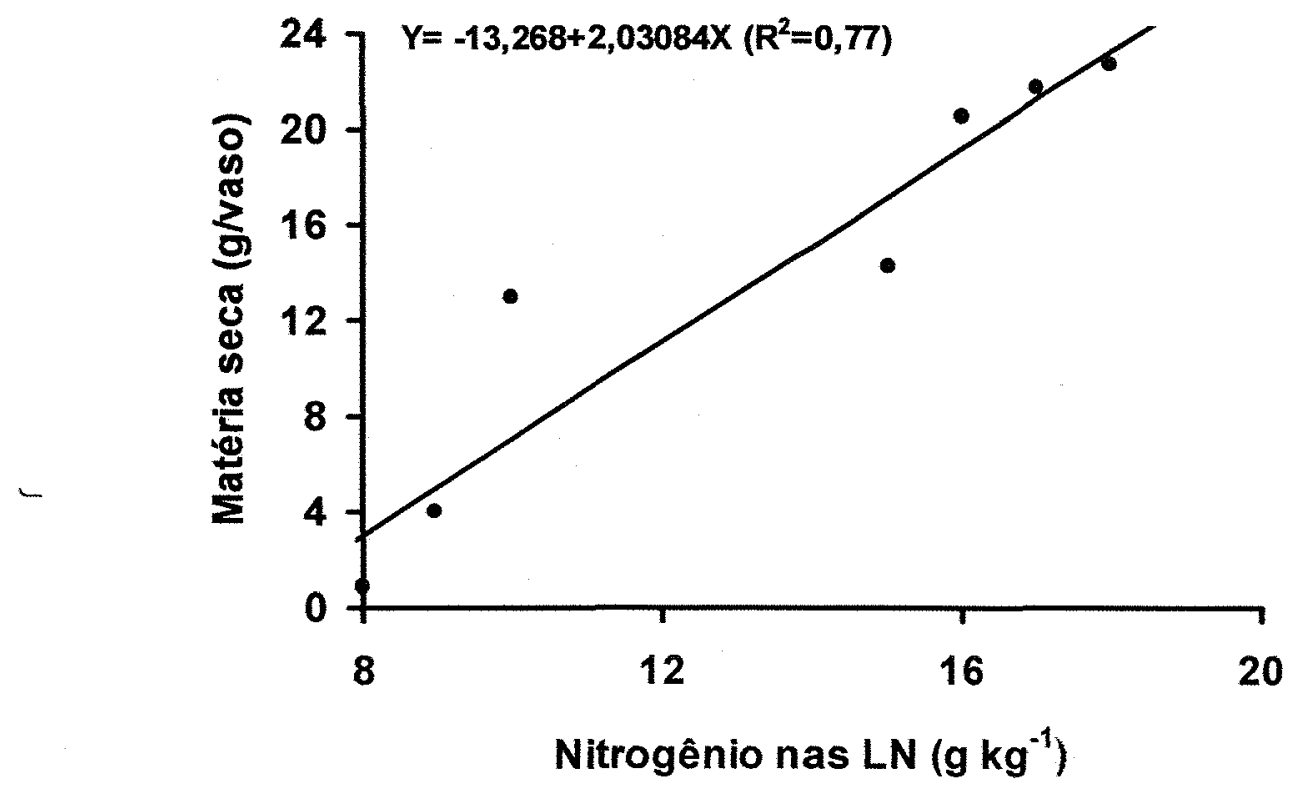

Figura 26. Relação entre a concentração de nitrogênio nas lâminas de folhas novas (LN) e a produção de matéria seca da parte aérea, no primeiro corte, do Panicum maximum cultivar Mombaça.

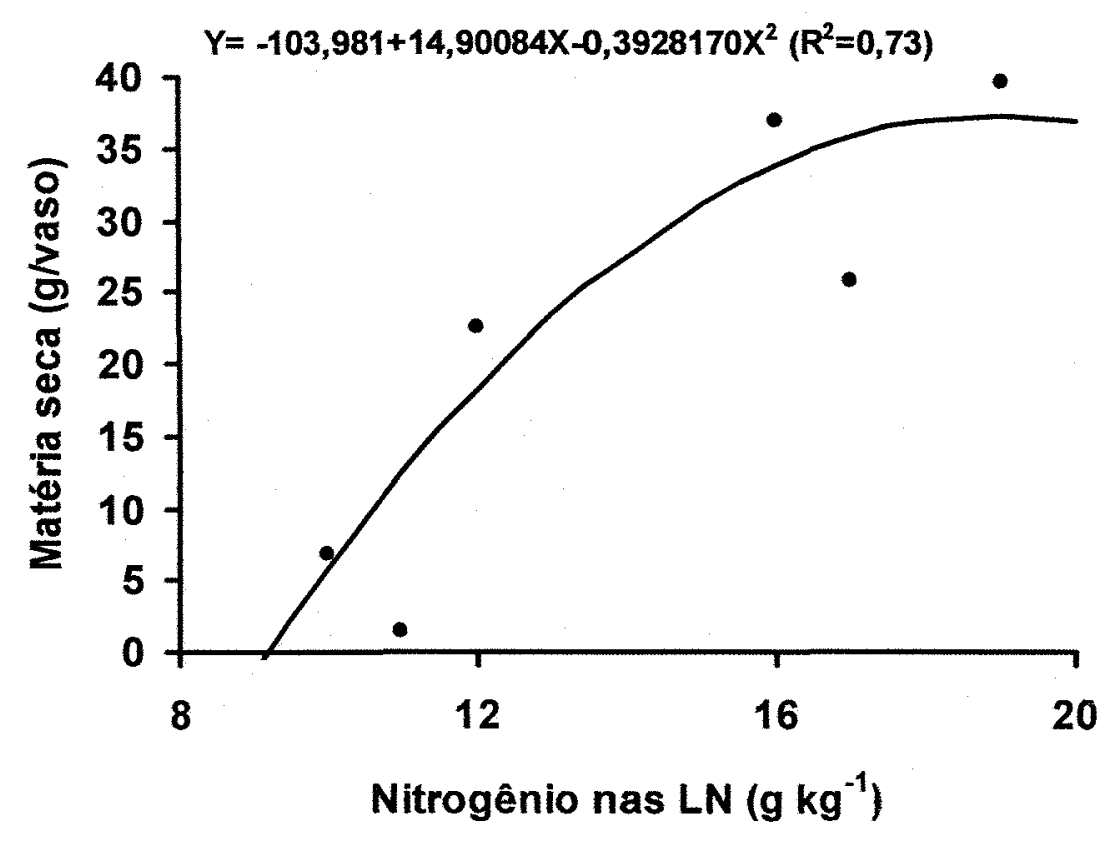

Figura 27. Relação entre a concentração de nitrogênio nas lâminas de folhas novas (LN) e a produção de matéria seca da parte aérea, no segundo corte, do Panicum maximum cultivar Mombaça. 
No segundo corte o valor do nível crítico encontrado para a concentração de nitrogênio nas lâminas de folhas novas foi de $16 \mathrm{~g} \mathrm{~kg}^{-1}$ (Figura 27). Santos (1997) obteve valor semelhante para o nivel crítico $(14,5)$ no segundo crescimento da braquiária decumbens. Colozza (1998) encontrou valor de 22,9 para o nível crítico de nitrogênio nessa parte do capim-Mombaça, no segundo corte.

O valor em SPAD correspondente ao nível crítico de nitrogênio nas lâminas de folhas novas do capim-Mombaça, no primeiro e no segundo corte, foi de 45 e 41 unidades SPAD, respectivamente, que corresponderam a 16,5 e $16 \mathrm{~g} \mathrm{~kg}^{-1}$, nos respectivos cortes (Figuras 28 e 29).

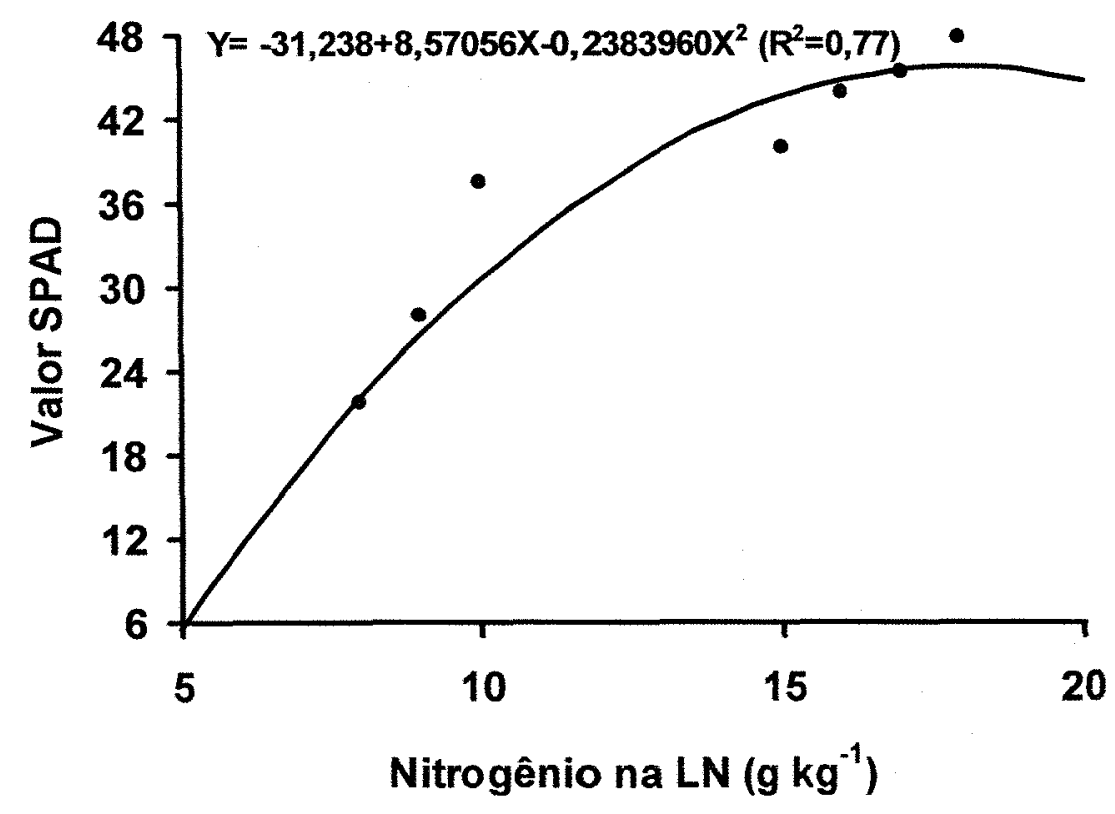

Figura 28. Relação entre a concentração de nitrogênio nas lâminas de folhas novas (LN) no primeiro corte com o valor SPAD medido nas lâminas de folhas novas do Panicum maximum cultivar Mombaça. 
Colozza (1998) encontrou valores SPAD correspondentes aos niveis críticos de nitrogênio entre 32,0 e 38,6 unidades SPAD, para valores de níveis críticos de nitrogênio total de 20,8 e $22,9 \mathrm{~g} \mathrm{~kg}^{-1}$ de matéria seca para o primeiro e segundo crescimento, respectivamente.

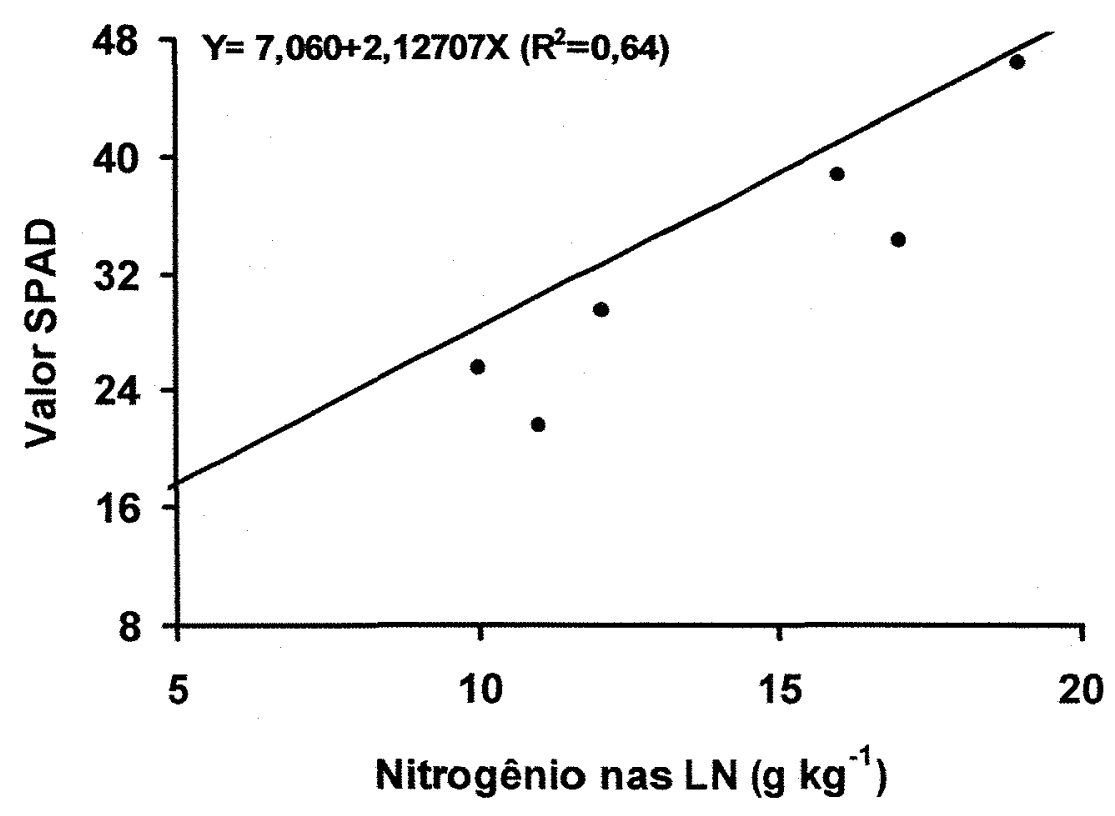

Figura 29. Relação entre a concentração de nitrogênio nas lâminas de folhas novas (LN) no segundo corte com o valor SPAD medido nas lâminas de folhas novas do Panicum maximum cultivar Mombaça. 


\section{CONCLUSÕES}

$\sqrt{ }$ As doses de nitrogênio proporcionaram aumentos na produção de matéria seca da parte aérea e das raizes, no número de perfilhos, na concentração de nitrogênio total da matéria seca da parte aérea e das raízes e na área foliar do capim-Mombaça.

$\sqrt{ } \quad$ A atividade da enzima redutase do nitrato nas folhas do Panicum maximum cultivar Mombaça variou em função do incremento nas doses de nitrogênio, em ambos os cortes.

$\sqrt{ }$ A concentração de nitrogênio aumentou em todas as partes do Panicum maximum cultivar Mombaça (folhas não-expandidas, lâminas de folhas novas, lâminas de folhas velhas, colmo mais bainha e raízes) com o incremento das doses de nitrogênio na solução nutritiva.

$\sqrt{ } \quad$ As lâminas de folhas novas foram adequadas para a avaliação do estado nutricional em nitrogênio do capim-Mombaça, o nível crítico determinado nesse componente da planta foi de 16 a $16,5 \mathrm{~g} \mathrm{~kg}^{-1} \mathrm{e}$ o valor SPAD associado a esse nível crítico foi de 41 a 45 . 


\section{REFERÊNCIAS BIBLIOGRÁFICAS}

ABREU, J.B.R. Níveis de nitrogênio e proporções de nitrato e amônio afetando produção, atividade da redutase do nitrato e composição de três gramíneas forrageiras. Piracicaba, 1994. 103p. Dissertação (Mestrado) - Escola Superior de Agricultura "Luiz de Queiroz", Universidade de São Paulo.

ABREU, J.B.R. Produção e nutrição dos capins Tanzânia-1 e Marandu em função de estádios de crescimento e adubação nitrogenada. Piracicaba, 1999. 99p. Tese (Doutorado) - Escola Superior de Agricultura "Luiz de Queiroz", Universidade de São Paulo.

ANDRADE, S.R.M. Efeito da proporção $\mathrm{NH}_{4}{ }^{+} / \mathrm{NO}_{3}{ }^{-}$na composição da fração nitrogenada na atividade de enzimas de redução e assimilação de nitrogênio em plantas de capim-Colonião (Panicum maximum Jacq). Viçosa, 1994. 49p. Dissertação (Mestrado), Universidade Federal de Viçosa.

ARONOVICH, S. O capim colonião e outros cultivares de Panicum maximum Jacq. : Introdução e evolução do uso no Brasil. In: SIMPÓSIO SOBRE MANEJO DE PASTAGEM, 12, Piracicaba, 1995. Anais. Piracicaba: FEALQ, 1995. p.1-20. 
BARBOSA, M.A.A. de F.; CECATO, U; ONORATO, W.M. et al. Efeito do intervalo entre cortes no crescimento de folhas do capim Mombaça (Panicum maximum Jacq. Cv. Mombaça). In: REUNIÃO ANUAL DA SOCIEDADE BRASILEIRA DE ZOOTECNIA, 35., Botucatu, 1998, Anais. Botucatu: SBZ, 1998, p. 504-506.

CECATO, U. Influência da frequência de corte, de niveis e formas de aplicação do nitrogênio sobre a produção, a composição bromatológica e algumas características de rebrota do capim-Aruana (Panicum maximum Jacq. cv. Aruana). Jaboticabal, 1993. 112p. Tese(Doutorado) - Faculdade de Ciências Agrárias e Veterinárias de Jaboticabal. - Universidade Estadual Paulista.

CHAPMAN, D.F.; LEMAIRE, G. Morphogenetic and structural determinants of plant regrowth after defoliation. In: International Grassland Congress, 17, New Zealand, 1993, Resumos. New Zealand, 1993, p. 95-104.

COLOZZA, M.T. Rendimento e diagnose foliar dos capins Aruana e Mombaça cultivados em latossolo vermelho-amarelo adubado com doses de nitrogênio. Piracicaba, 1998, 126p. Tese (Doutorado) - Escola Superior de Agricultura "Luiz de Queiroz", Universidade de São Paulo.

CORREA, B.D. Doses de nitrogênio e de magnésio afetando aspectos produtivos e bioquímicos dos capins Colonião, Tanzânia-1 e Vencedor. Piracicaba, 1996. 76 p. Dissertação (Mestrado) - Escola Superior de Agricultura "Luiz de Queiroz", Universidade de São Paulo. 
CORREA, L. de A.; FREITAS, A.R. de; BATISTA, L.A.R. Niveis de nitrogênio e frequências de corte em 12 gramíneas forrageiras tropicais. I-Produção de matéria seca. In: REUNIÄO ANUAL DA SOCIEDADE BRASILEIRA DE ZOOTECNIA, 35., Botucatu, 1998, Anais. Botucatu: SBZ, 1998. p.304-306

COSTA, C. Estudo da variação na estrutura da vegetação de dois cultivares de Panicum maximum Jacq. (Colonião e Tobiatã) submetidos a diferentes tipos de manejo. Jaboticabal. 1990. 96p. Tese (Doutorado) - Faculdade de Ciências Agrárias e Veterinárias de Jaboticabal, Universidade Estadual Paulista.

COSTA, M.N.X. da. Influência de épocas e doses de adubação nitrogenada na produção estacional de dois capins. Piracicaba. 1999. 63p. Dissertação (Mestrado) - Escola Superior de Agricultura "Luiz de Queiroz", Universidade de São Paulo.

EMPRESA BRASILEIRA DE PESQUISA AGROPECUÁRIA. MOMBAÇA. Campo Grande: EMBRAPA /CNPGC, 1993. 5p.

EUCLIDES, U.P.B.; MACEDO, M.C.M.; OLIVEIRA, M.P. Avaliação de ecotipos de Panicum maximum sob pastejo em pequenas parcelas. In: REUNIÃO ANUAL DA SOCIEDADE BRASILEIRA DE ZOOTECNIA. 32, Brasilia, 1995. Anais. Brasilia: SBZ, 1995. p.97-99.

FAVORETTO, V.; CECATO, U.; GUIDELI, C. et al. Avaliação da estrutura da vegetação do capim-Colonião em função de práticas de manejo. In: REUNIĀO ANUAL DA SOCIEDADE BRASILEIRA DE ZOOTECNIA, 32., Brasilia, 1995. Anais. Brasília: SBZ, 1995. p. 45-47. 
FERNANDES, M. S.; ROSSIELO, R.O.P. Aspectos do metabolismo e utilização do nitrogênio em gramíneas tropicais. In: SIMPÓSIO SOBRE CALAGEM E ADUBAÇÃO DE PASTAGENS, 1, Nova Odessa, 1985. Anais. Piracicaba: POTAFOS, 1986. p.93-123.

FERRAGINE, M.D.C. Combinação de doses de nitrogênio e potássio na nutrição mineral de capim-braquiária. Piracicaba, 1998. 84p. Dissertação (Mestrado) - Escola Superior de Agricultura "Luiz de Queiroz", Universidade de São Paulo.

FURLANI Jr. E.; NAKAGAWA, J.; BULHÕES, L.J. et al. Correlação entre leituras de clorofila $e$ níveis de nitrogênio aplicados em feijoeiro. Bragantia, v.55, n.1, p. 171-175, 1996.

GASTAL, F.; BELANGER, G.; LEMAIRE, G. A model of the leaf extention rate of tall fescue in response to nitrogen and temperature. Annals of Botany. v.70. p. $437-442,1992$.

HERLING, V.R.; RODRIGUES, L.R.A.; NOGUEIRA FILHO, J.C.M.; LIMA, C.G. de; RODRIGUES, T. de J. D. Efeitos de niveis de nitrogênio sobre as cultivares Colonião e Centenário (Panicum maximum Jacq.) I. Características Fisiológicas. In: REUNIÃO ANUAL DA SOCIEDADE BRASILEIRA DE ZOOTECNIA, 32., Brasília, 1995. Anais. Brasília: SBZ, 1995. P. 71-73. 
HOFFMANN, C.R.; FAQUIN, V.; GUEDES, G.A.A. et al. Respostas da Braquiária e do Colonião às aplicações de nitrogênio, fósforo, potássio e enxofre em latossolo da região noroeste do Paraná. In: REUNIÃO BRASILEIRA DE FERTILIDADE DO SOLO E NUTRIÇÃO DE PLANTAS, 20, Piracicaba, 1992. Anais. Piracicaba: Sociedade Brasileira de Ciência do Solo, 1992. p.268-269.

HOPKINS, W.G. Introduction to plant physiology. New York: John Wiley \& Sons, Inc., 1995. 464p.

JANK, L. Melhoramento e seleção de variedades de Panicum maximum. In: SIMPÓSIO SOBRE MANEJO DA PASTAGEM, 12, Piracicaba, 1995. Anais. Piracicaba: FEALQ, 1995. p. 21-58.

LANGER, R.H.M. Tillering in herbage grasses. Herbage Abstrats, v.33, n.3, p.141-148, 1963.

LEHNINGER, A.L. Bioquímica. São Paulo: Edgard Blucher, 1976, v.3, p.441595.

LIMA FILHO, O.F. de; MALAVOLTA, E.; CABRAL, C.P. Avaliação preliminar de um medidor portátil de clorofila como ferramenta para o manejo da adubação nitrogenada do cafeeiro. Arquivos de Biologia e Tecnologia, v.40, n.3, p. 642-650, 1997.

MACHADO, A.O.; CECATO, U.; MIRA, R.T et al. Avaliação de genótipos de Panicum maximum (Jacq.) em duas alturas de corte. In: REUNIÃO ANUAL 
DA SOCIEDADE BRASILEIRA DE ZOOTECNIA, 34., Juiz de Fora, 1997. Anais. Juiz de Fora: SBZ, 1997. P. 219-221.

MALAVOLTA, E. Elementos de nutrição mineral de plantas. São Paulo: Agronômica Ceres, 1980. 251p.

MALAVOLTA, E.; LIEM, T.H.; PRIMAVESI, A.C.P.A. Exigências nutricionais das plantas forrageiras. In: REUNIÃO BRASILEIRA DE FERTILIDADE DO SOLO E NUTRIÇÃO DE PLANTAS, 21, Petrolina, 1994. Anais. Petrolina: SBCS/EMBRAPA-CPATSA, 1994. p.31-76.

MALAVOLTA, E.; VITTI, G.C.; OLIVEIRA, S.A. Avaliação do estado nutricional das plantas - princípios e aplicação. Piracicaba, POTAFOS, 1997. 319p.

MENGEL, K.; KIRKBY, E. Principles of plant nutrition. 4ed. Bern; International Potash Institute, 1987. 687p.

MINOLTA CAMERA Co. Manual for chlorophyll meter Spad-502. Osaka, 1989. 22p.

MONTEIRO, F.A. Nutrição mineral e adubação. In: SIMPÓSIO SOBRE MANEJO DA PASTAGEM, 12, Piracicaba, 1995. Piracicaba: FEALQ, 1995. p.219-244.

MONTEIRO, F.A.; WERNER, J.C. Efeitos das adubações nitrogenada e fosfatada em capim colonião, na formação e em pasto estabelecido. Boletim de Indústria Animal, v.34, n.1, p. 91-101, 1977. 
MULDER, E.G.; BOXMA, R.; VAN VEEN, W.L. Nitrate reduction in plant tissue. Plant and Soil, v.10, n.3, p. 335-355, 1959.

NABINGER, C. Eficiência do uso de pastagens: disponibilidade e perdas de foragem. In: SIMPÓSIO SOBRE MANEJO DA PASTAGEM, 14, Piracicaba, 1997. Piracicaba: FEALQ, 1997. p.213-251.

PACHECO, A.B.; NOGUEIRA, A.; PAULA, M.B. et al. Efeito de diferentes níveis de $N$ e $P$ na produção de matéria seca de três cultivares de gramíneas forrageiras. In: REUNIÃO BRASILEIRA DE FERTILIDADE DO SOLO E NUTRIÇÃO DE PLANTAS, 22, Manaus, 1996. Resumos. Manaus: Ed. da Universidade do Amazonas, 1996. p.391-392.

PAULINO, V.T.; SCHUNKE, R.; CANTARELLA, H. Avaliação do nivel de nitrogênio em quatro cultivares de Panicum maximum Jacq. através da medida indireta de clorofila. In: REUNIÃO ANUAL DA SOCIEDADE BRASILEIRA DE ZOOTECNIA, 35., Botucatu, 1998, Anais. Botucatu: SBZ, 1998. p. 427-428.

RODRIGUES, L.R.A.; REIS, R.A. Bases para o estabelecimento do manejo de capins do gênero Panicum. In: SIMPÓSIO SOBRE MANEJO DA PASTAGEM, 12, Piracicaba, 1995. Anais. Piracicaba: FEALQ, 1995. p.197-217.

RUFTY, T.W.JR; THOMAS, J.F.; REMMLEER, J.L. et al. Intracellular localization of nitrate reductase in roots. Plant Physiology, v.82, n.3, p.675-680, 1986. 
SANTOS, A.R. Diagnose nutricional e respostas do capim-braquiária submetido a doses de nitrogênio e enxofre. Piracicaba, 1997. 115p. Tese (Doutorado) - Escola Superior de Agricultura "Luiz de Queiroz", Universidade de São Paulo.

SANTOS, A.R.; CORREA, B.D.; MONTEIRO, F.A. Efeito de niveis de nitrogênio sobre o rendimento de matéria seca, teor de nitrogênio e perfilhamento em Panicum maximum cultivar Vencedor. In: CONGRESSO BRASILEIRO DE CIÊNCIA DO SOLO, 25., Viçosa, 1995. Resumos. Viçosa: Sociedade Brasileira de Ciência do Solo, 1995. p. 741-742.

SANZONOWICZ, C. Recomendação e prática de adubação e calagem na região centro-oeste do Brasil. In: SIMPÓSIO SOBRE CALAGEM E ADUBAÇÃO DE PASTAGENS, 1, Nova Odessa, 1985. Anais. Piracicaba: POTAFOS, 1986. p.309-334.

SARRUGE, J.R. Soluções nutritivas. Summa Phytopathologica, v.1, n.3, p.231-233, 1975.

SARRUGE, J.R.; HAAG, H.P. Análises químicas em plantas. Piracicaba: ESALQ, Departamento de Química, 1974. 54p.

SAS INSTITUTE INCORPORATION. Propriety Software Release 6.08. Cary, NC USA, 1989.

SHEN, Z.; LIANG, Y.; SHEN, K. Effect of boron on the nitrate reductase activity in oilseed rape plants. Journal of Plant Nutrition, v.16, p.1229-1239, 1993. 
SRIVASTAVA, H.S. Regulation of nitrate reductase activity in higher plants. Phytochemistry, v.19, n.5, p. 725-733, 1980.

ULRICH, A.; HILLS, F.J. Plants analysis as an aid fertilizing sugar crops: part I. Sugar beets. In: WALSH, L.M.; BEATON, J.D. (Ed) Soil testing and plant analysis. Madison: Soil Science Society of America, 1973. p.271-288.

VALLEJOS, A.; PIZARRO, E. A.; CHÁVES, C. et al. Evaluación agronómica de gramíneas en Guapiles, Costa Rica.2. Ecotipos de Panicum maximum. Pasturas Tropicales, v.11, n.2, p.10-15, 1989.

WERNER, J.C. Adubação de pastagens. Nova Odessa: Instituto de Zootecnia, 1986. 49p. (IZ. Boletim Técnico, 18). 